\title{
Microbial Quality of the Nation's Ground-Water Resources, 1993-2004
}

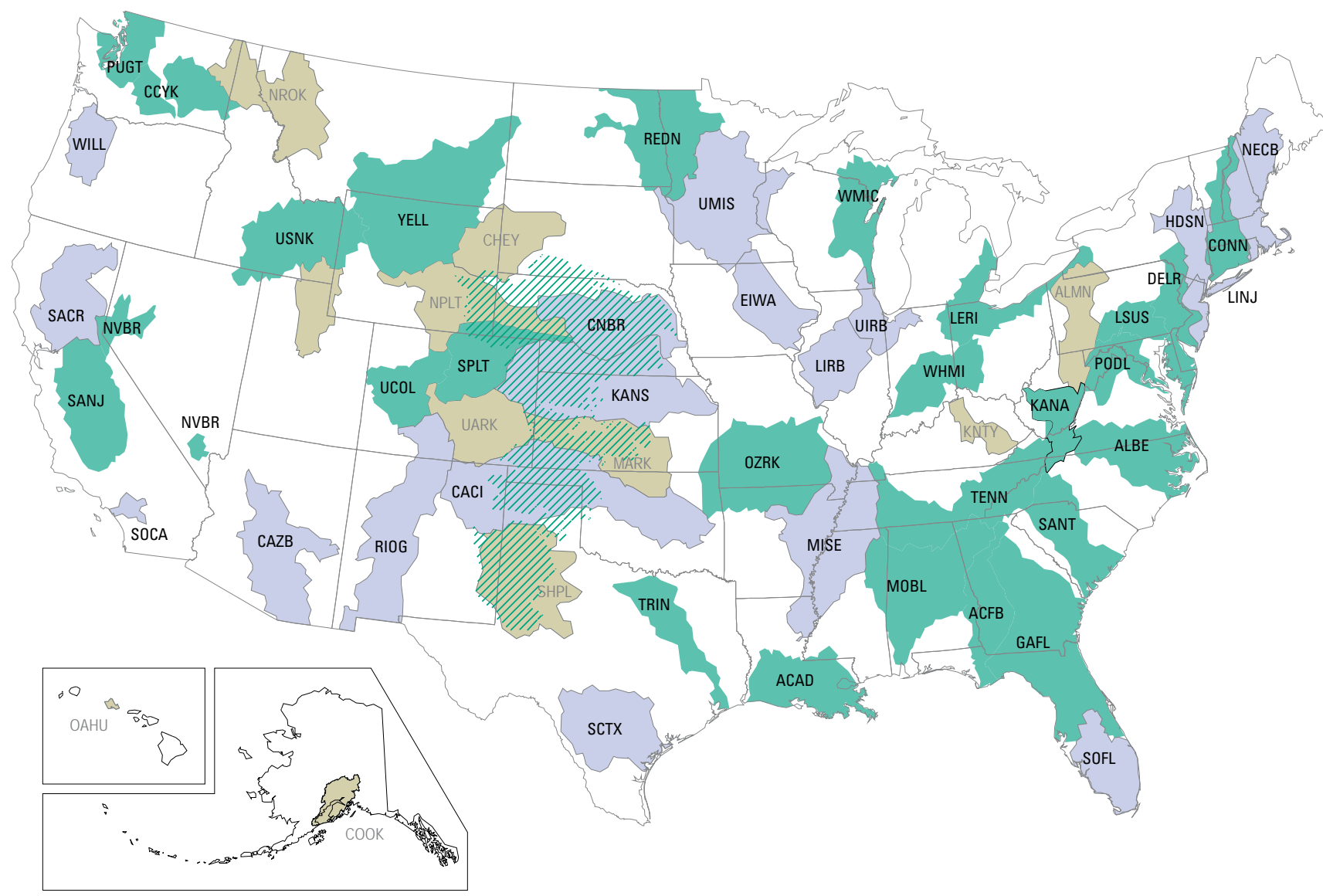

Scientific Investigations Report 2006-5290 



\section{Microbial Quality of the Nation's Ground-Water Resources, 1993-2004}

By S.S. Embrey and D.L. Runkle

National Water-Quality Assessment Program—Principal Aquifers

Scientific Investigations Report 2006-5290 


\section{U.S. Department of the Interior DIRK KEMPTHORNE, Secretary}

\section{U.S. Geological Survey \\ Mark D. Myers, Director}

\section{U.S. Geological Survey, Reston, Virginia: 2006}

For product and ordering information:

World Wide Web: http://www.usgs.gov/pubprod

Telephone: 1-888-ASK-USGS

For more information on the USGS--the Federal source for science about the Earth, its natural and living resources, natural hazards, and the environment:

World Wide Web: http://www.usgs.gov

Telephone: 1-888-ASK-USGS

Any use of trade, product, or firm names is for descriptive purposes only and does not imply endorsement by the U.S. Government.

Although this report is in the public domain, permission must be secured from the individual copyright owners to reproduce any copyrighted materials contained within this report.

Suggested citation:

Embrey, S.S., and Runkle, D.L., 2006, Microbial quality of the Nation's ground-water resources, 1993-2004: U.S.

Geological Survey Scientific-Investigations Report 2006-5290, 34 p. 


\section{Foreword}

The U.S. Geological Survey (USGS) is committed to providing the Nation with accurate and timely scientific information that helps enhance and protect the overall quality of life and that facilitates effective management of water, biological, energy, and mineral resources (http://www.usgs.gov/). Information on the quality of the Nation's water resources is critical to assuring the long-term availability of water that is safe for drinking and recreation and suitable for industry, irrigation, and habitat for fish and wildlife. Population growth and increasing demands for multiple water uses make water availability, now measured in terms of quantity and quality, even more essential to the long-term sustainability of our communities and ecosystems.

The USGS implemented the National Water-Quality Assessment (NAWQA) Program in 1991 to support national, regional, and local information needs and decisions related to water-quality management and policy (http://water.usgs.gov/nawqa). Shaped by and coordinated with ongoing efforts of other Federal, State, and local agencies, the NAWQA Program is designed to answer: What is the condition of our Nation's streams and ground water? How are the conditions changing over time? How do natural features and human activities affect the quality of streams and ground water, and where are those effects most pronounced? By combining information on water chemistry, physical characteristics, stream habitat, and aquatic life, the NAWQA Program aims to provide science-based insights for current and emerging water issues and priorities.

From 1991-2001, the NAWQA Program completed interdisciplinary assessments in 51 of the Nation's major river basins and aquifer systems, referred to as Study Units (http://water.usgs.gov/ nawqa/studyu.html). Baseline conditions were established for comparison to future assessments, and long-term monitoring was initiated in many of the basins. During the next decade, 42 of the 51 Study Units will be reassessed so that 10 years of comparable monitoring data will be available to determine trends at many of the Nation's streams and aquifers. The next 10 years of study also will fill in critical gaps in characterizing water-quality conditions, enhance understanding of factors that affect water quality, and establish links between sources of contaminants, the transport of those contaminants through the hydrologic system, and the potential effects of contaminants on humans and aquatic ecosystems.

The USGS aims to disseminate credible, timely, and relevant science information to inform practical and effective water-resource management and strategies that protect and restore water quality. We hope this NAWQA publication will provide you with insights and information to meet your needs, and will foster increased citizen awareness and involvement in the protection and restoration of our Nation's waters.

The USGS recognizes that a national assessment by a single program cannot address all waterresource issues of interest. External coordination at all levels is critical for a fully integrated understanding of watersheds and for cost-effective management, regulation, and conservation of our Nation's water resources. The NAWQA Program, therefore, depends on advice and information from other agencies—Federal, State, interstate, Tribal, and local—as well as nongovernmental organizations, industry, academia, and other stakeholder groups. Your assistance and suggestions are greatly appreciated.

Robert M. Hirsch

Associate Director for Water 
This page intentionally left blank. 


\section{Contents}

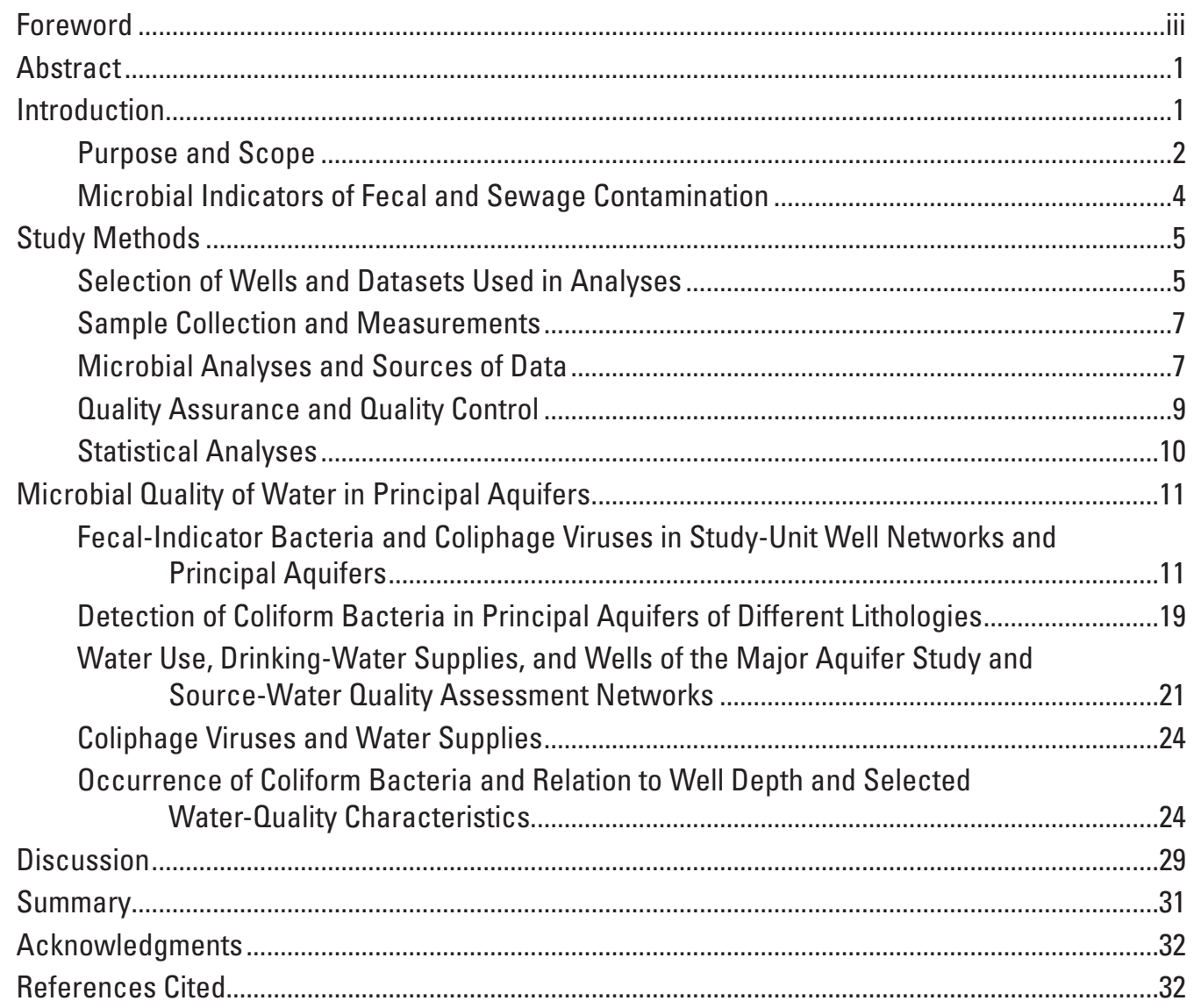




\section{Figures}

Figure 1. Map showing study units of the National Water-Quality Assessment program in which microbiological samples were collected from wells, 1993-2004

Figure 2. Graph showing numbers of test results for fecal-indicator microorganisms by each analytical method for environmental and quality-control samples collected from wells in 22 study units of the National Water-Quality Assessment program, 1993-2004

Figure 3. Maps showing locations of wells in principal aquifers that tested positive for fecal-indicator bacteria and wells where fecal-indicator bacteria were not detected in samples collected for the National Water-Quality Assessment program, 1993-2004

Figure 4. Graph showing number of wells sampled and number of wells with detections of coliform bacteria in samples collected in 22 study units of the National Water-Quality Assessment program, 1993-2004

Figure 5. Graphs showing percentage of wells testing positive for total coliform bacteria and Escherichia coli, and concentrations of coliform bacteria by study network in samples collected in 22 study units of the National Water-Quality Assessment program, 1993-2004

Figure 6. Graphs showing percentage of wells testing positive for coliform bacteria, and significantly different ( $p$-value $<0.0006$ ) detection frequencies of total coliform bacteria by principal aquifer from data collected in 22 study units of the National Water-Quality Assessment program, 1993-2004

Figure 7. Graphs showing percentage of detections of coliform bacteria and coliphage virus in wells sampled as part of the major aquifer studies and source-water quality assessments for the National Water-Quality Assessment program, 1993-2004

Figure 8. Boxplot showing concentrations of total coliform and Escherichia coli by principal aquifer in samples collected in 22 study units of the National Water-Quality Assessment program, 1993-2004

Figure 9. Graphs showing percentage of wells testing positive for coliform bacteria, and significantly different detection frequencies $(p$-value $<0.002)$ of total coliform bacteria with respect to aquifer lithology

Figure 10. Boxplot showing concentrations of total coliform and Escherichia coliby principal aquifer lithology in samples collected in 22 study units of the National Water-Quality Assessment program, 1993-2004

Figure 11. Graph showing percentage of major aquifer study (MAS) and source-water quality assessment (SWQA) wells sampled by class of water use in 22 study units of the National Water-Quality Assessment program, 1993-2004

Figure 12. Graph and boxplot showing percentage of wells testing positive for coliform bacteria, and concentrations of coliform bacteria by class of water use in samples collected in major aquifer study (MAS) and source-water quality assessment (SWOA) wells in 22 study units of the National Water-Quality Assessment program, 1993-2004

Figure 13. Graphs showing relation of the presence or absence of coliphage virus to concentrations of total coliforms for wells in the major aquifer study (MAS) networks and source-water quality assessment (SWQA) networks, and for principal aquifers with coliphage-positive wells 


\section{Figures-Continued}

Figure 14. Boxplot showing distributions of well depths for the major aquifer study (MAS), land use study (LUS), and source-water quality assessment (SWQA) networks, and distribution of well depths for the classes of water use, from data collected in 22 study units of the National Water-Quality Assessment program, 1993-2004

Figure 15. Boxplot showing distribution of well depths in the 16 principal aquifers studied by the National Water-Quality Assessment program, 1993-2004

Figure 16. Scatterplot showing total-coliform concentrations and depths of wells for all 16 principal aquifers combined on the basis of the median depths of sampled wells, from data collected in 22 study units of the National Water-Quality Assessment program, 1993-2004

Figure 17. Boxplots showing detections of total-coliform bacteria with concentrations of dissolved oxygen, nitrite-plus-nitrate nitrogen, and orthophosphate in samples collected from wells in 22 study units of the National Water-Quality Assessment program, 1993-2004

\section{Tables}

Table 1. Total estimated withdrawals of water from selected principal aquifers and withdrawals used for public supplies, irrigation, and self-supplied industrial in the United States, 2000

Table 2. Principal aquifers, primary lithology of the aquifers, well-sampling networks within each study unit, and the total number of wells sampled during water years 1993-2004.

Table 3. Consolidations and adjustments to the raw microbiological and associated ground-water data by study unit and network, water use, principal aquifer, and lithology

Table 4. Summary of microbiological data collected from wells in major aquifer study, land-use study, and source-water quality assessment networks in 22 study units of the National Water-Quality Assessment Program, 1993-2004

Table 5. Summary of microbiological data collected from wells in each principal aquifer in 22 study units of the National Water-Quality Assessment Program, 1993-2004

Table 6. Summary of microbiological data, by type of principal-aquifer lithology, collected from wells in 22 study units of the National Water-Quality Assessment program, 1993-2004

Table 7. Summary of microbiological data collected from major aquifer study and source-water-quality assessment wells used for domestic, public supply, and other purposes, and from unused wells by the National Water-Quality Assessment Program, 1993-2004

Table 8. Summary of coliphage data collected from major aquifer study and source-water quality assessment wells in each principal aquifer studied by the National Water-Quality Assessment program, 1993-2004 


\section{Conversion Factors and Abbreviations, Acronyms, and Symbols}

Conversion Factors

\begin{tabular}{lll}
\hline Multiply & By & To obtain \\
\hline cubic foot $\left(\mathrm{ft}^{3}\right)$ & 0.02832 & cubic meter \\
foot $(\mathrm{ft})$ & 0.3048 & meter \\
gallon (gal) & 3.785 & liter \\
gallon per minute $(\mathrm{gal} / \mathrm{min})$ & 0.06309 & liter per second \\
gallon per day $(\mathrm{gal} / \mathrm{d})$ & 0.003785 & cubic meter per day \\
inch of mercury at $60^{\circ} \mathrm{F}(\mathrm{in} \mathrm{Hg})$ & 3.377 & kilopascal \\
mile (mi) & 1.609 & kilometer \\
million gallons per day $(\mathrm{Mgal} / \mathrm{d})$ & 0.04381 & cubic meter per second \\
ounce, fluid (fl. Oz) & 0.02957 & liter \\
ounce, avoirdupois $(\mathrm{oz})$ & 28.35 & gram \\
pound, avoirdupois $(\mathrm{lb})$ & 0.4536 & kilogram \\
\hline
\end{tabular}

Temperature in degrees Celsius $\left({ }^{\circ} \mathrm{C}\right)$ may be converted to degrees Fahrenheit $\left({ }^{\circ} \mathrm{F}\right)$ as follows:

$$
{ }^{\circ} \mathrm{F}=\left(1.8 \times{ }^{\circ} \mathrm{C}\right)+32
$$

Temperature in degrees Fahrenheit $\left({ }^{\circ} \mathrm{F}\right)$ may be converted to degrees Celsius $\left({ }^{\circ} \mathrm{C}\right)$ as follows:

$$
{ }^{\circ} \mathrm{C}=\left({ }^{\circ} \mathrm{F}-32\right) / 1.8
$$

Specific conductance is given in microsiemens per centimeter at 25 degrees Celsius $(\mu \mathrm{S} / \mathrm{cm}$ at $\left.25^{\circ} \mathrm{C}\right)$.

Concentrations of chemical constituents in water are given in milligrams per liter (mg/L) or micrograms per liter $(\mu \mathrm{g} / \mathrm{L})$.

Concentrations of microorganisms in water are given in colony forming units per 100 milliliters (CFU/100mL). 
Conversion Factors and Abbreviations, Acronyms, and Symbols-Continued

\begin{tabular}{ll}
\hline $\begin{array}{c}\text { Abbreviation, } \\
\text { Acronym, or Symbol }\end{array}$ & \\
\hline ACFB & Alplachicola-Chattahoochee-Flint study unit \\
ALBE & Albemarle-Pamlico study unit \\
APHA & American Public Health Association \\
CCYK & Central Columbia Plateau-Yakima study unit \\
E. coli & Escherichia coli \\
GAFL & Georgia-Florida study unit \\
HPGW & High Plains Ground Water study unit \\
KANA & Kanawha study unit \\
LERI & Lake Erie study unit \\
LSUS & Lower Susquehanna study unit \\
LUS & land-use studies \\
MAS & major-aquifer studies \\
NAWQA & National Water-Quality Assessment Program \\
NFM & National Field Manual \\
NWIS & National Water Information Services \\
OWML & Ohio Water Microbiological Laboratory \\
OZRK & Ozark Plateaus study unit \\
PODL & Potomac-Delmarva study unit \\
PUGT & Puget Sound Basin study unit \\
QA & quality assurance \\
QC & quality control \\
REDN & Red River of the North study unit \\
SANJ & San Joaquin study unit \\
SANT & Santee study unit \\
SPLT & South Platte study unit \\
SWQA & source-water quality assessments \\
TENN & lower and upper Tennessee study unit \\
TRIN & Trinity study unit \\
UCOL & Upper Colorado study unit \\
USEPA & U.S. Environmental Protection Agency \\
USGS & U.S. Geological Survey \\
USNK & Upper Snake study unit \\
$<$ & less than \\
greater than \\
\hline
\end{tabular}


This page intentionally left blank. 


\title{
Microbial Quality of the Nation's Ground-Water Resources, 1993-2004
}

\author{
S.S. Embrey and D.L. Runkle
}

\section{Abstract}

As part of the National Water-Quality Assessment (NAWQA) program, microbiological data were collected from wells in 22 NAWQA study units during 1993-2004. The wells constituted the sampling networks for three major NAWQA efforts-the major aquifer study, the land-use study, and source-water quality assessments of ground water used for public supplies. Sixteen principal aquifers were represented by these well networks. Samples of untreated ground water were analyzed for concentrations of fecal-indicator bacteria, which included the total-coliform bacteria, fecal-coliform bacteria, and Escherichia coli, and for the presence of somatic and male-specific coliphage viruses.

Analyses of the samples showed that coliform bacteria occur relatively frequently-nearly 30 percent of all wells tested positive-and that domestic wells commonly are contaminated by total coliform bacteria, with 33 percent of these wells testing positive. Coliphage viruses were present in 10 percent or fewer of the wells sampled in the Central Columbia Plateau-Yakima, Georgia-Florida, San Joaquin, and Trinity study units, which represent the Columbia Plateau, Floridan, Central Valley, and Coastal Lowlands principal aquifers, respectively. The frequency of detections and concentrations of total coliform bacteria generally were higher in samples from domestic wells than in samples from publicsupply wells; in fractured or porous rock materials (carbonate rocks) than in unconsolidated materials (mixtures of sand, gravel, clay); and in principal aquifers with median depths of sampled wells ranging from 100 to 200 feet than in principal aquifers with median depths of sampled wells less than 100 feet or greater than 200 feet.

The waters most affected by the presence of coliform bacteria were those in the Valley and Ridge, the Floridan, and the Piedmont and Blue Ridge aquifers, where more than 50 percent of the study wells tested positive for these bacteria. The numbers of wells with detections of coliform bacteria were significantly lower for the Glacial Deposits, Stream and River Valley, Columbia Plateau, Basin and Range, High Plains, Southeastern Coastal Plain, and Coastal Lowlands aquifers. Of the 16 principal aquifers sampled, wells in the Valley and Ridge had the highest overall concentrations of total coliforms, with a median of 2 colony-forming units per
100 milliliters. Elevated concentrations of coliform bacteria (greater than 300 colony-forming units per 100 milliliters) also were reported for wells completed in the MississippianPennsylvanian aquifer and the Ordovician aquifer in lower Tennessee.

More than 50 percent of wells completed in carbonate or crystalline rocks tested positive for coliform bacteria. The Floridan, Piedmont and Blue Ridge, Ordovician (lower Tennessee), and Valley and Ridge aquifers are composed of these types of rocks. The lowest detection frequencies (less than 5 percent) were for wells in the Basin and Range and the Snake River aquifers. The materials that constitute these aquifers primarily are unconsolidated sand, gravel, and clay, or basalt with interbeds of sand, gravel, or clay.

No strong correlations between concentrations of total coliforms and well depths were identified, nor were there any correlations between total coliform concentrations and selected chemical constituents in the waters. Other factors, such as geohydrologic characteristics, proximity of contaminating sources, interactions with surface water, or well-construction features (including the age of the well), likely control the presence and transport of coliform bacteria in the ground water.

\section{Introduction}

In 1991, the U.S. Geological Survey (USGS) began the National Water-Quality Assessment (NAWQA) program to study the quality of the Nation's surface- and ground-water resources in more than 50 major river basins and aquifers. During the first 10 years of study (Cycle I), the primary goals of the program were to assess the water-quality conditions of the Nation's streams and ground water, the effects of human activities and natural features on the quality of water, and changes in the quality over time (Gilliom and others, 2001). In 2001, at the beginning of the program's second 10-year cycle (Cycle II) of intensive studies, NAWQA investigators returned to 14 major river-basin and aquifer systems (Gilliom and others, 2001). The second set of Cycle II studies of 14 systems began in 2004, and studies of a third set of 14 systems will begin in 2007, bringing the total to 42 of the Nation's most important river-basin and aquifer systems (Gilliom and 
others, 2001). Cycle II emphasizes building upon the initial assessments of water quality and studying in detail the longterm trends and the factors that affect water quality (Gilliom and others, 2001). NAWQA's Cycle II ground-water studies focus on regional assessments to evaluate water-quality conditions and trends in 16 or more principal aquifers, most of which underlie several states (Lapham and others, 2005).

NAWQA study units generally are defined by the boundaries of major-river basins and aquifer systems. Within each study unit, well networks were established to study the ground-water resources. In some cases, study units extended data collection outside of original geographic delineations to meet particular study unit, local, or national objectives. A group of network wells typically is sampled once during each 10 -year cycle; however, the sampling frequency can vary among the study units.

Fecal and sewage contamination of water can introduce pathogenic microorganisms, including bacteria and viruses, into a water resource (Geldreich, 1966). Data obtained from the collection of water samples from wells and analyzed for the presence of fecal-indicator microorganisms can be used in multiple ways. Perhaps most importantly, data indicating the presence or absence of fecal-indicator microorganisms in ground-water samples can help determine the suitability of a water resource for different purposes, particularly as a drinking-water resource. The collection of ground-water samples for the NAWQA program and the analyses for the occurrence of fecal-indicator bacteria and fecal-indicator viruses contributed to the discussion of the microbial quality of ground water in regions across the United States.

\section{Purpose and Scope}

This report summarizes microbiological data collected from wells by the NAWQA program from 1993 through 2004. The report describes (1) the occurrence and distribution of fecal-indicator bacteria and viruses in principal aquifers, and (2) the quality of water used for drinking-water supplies in the United States. All microbiological data collected in 27 NAWQA study units during Cycle I and several Cycle II studies (fig. 1) were inventoried for this analysis. However,

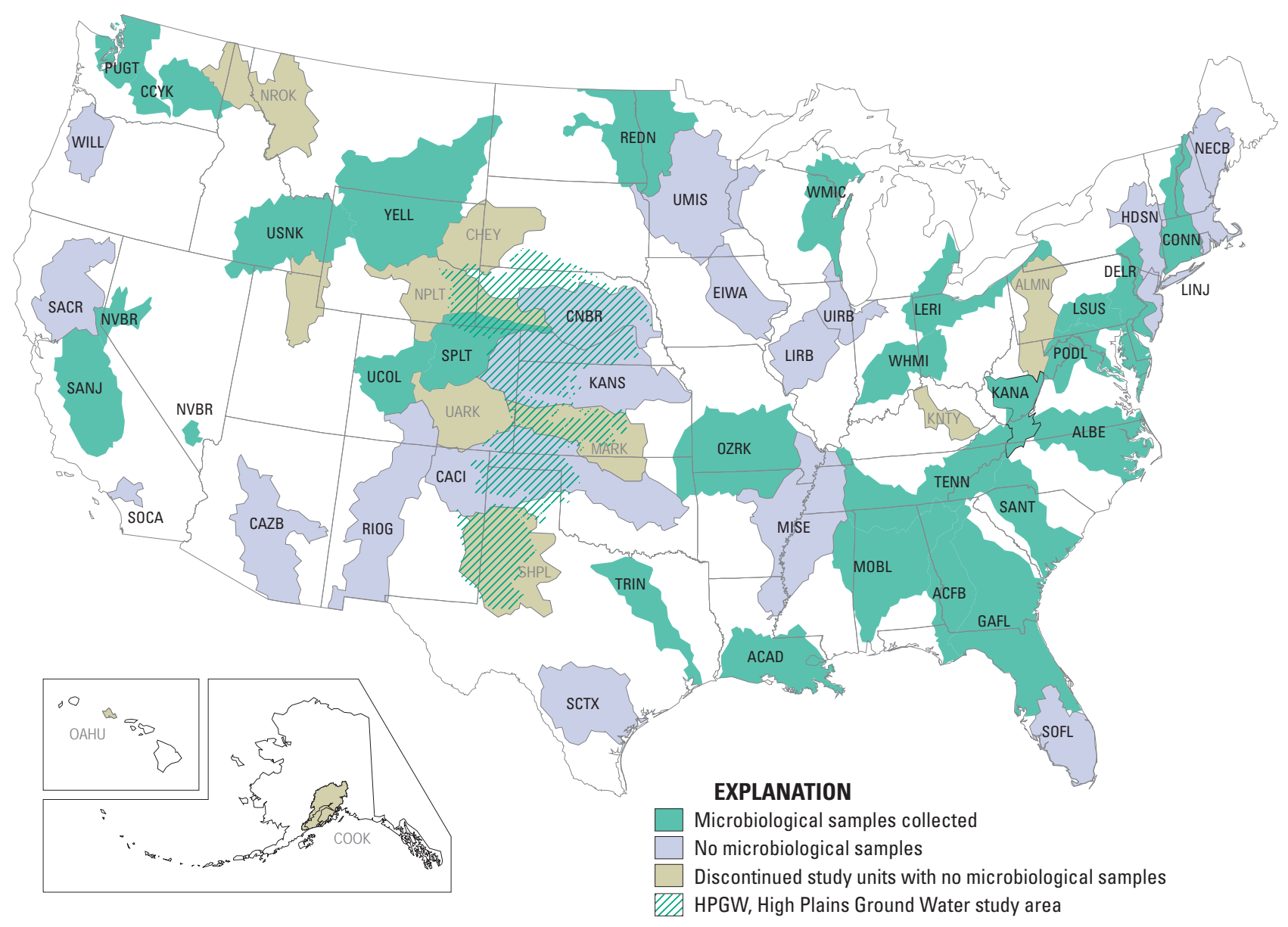

Figure 1. Study units of the National Water-Quality Assessment program in which microbiological samples were collected from wells, 1993-2004. (See table 2 for explanation of study-unit name abbreviations.) 
for describing the microbial quality of the ground-water resources of geographic regions and the principal aquifers, this assessment was limited to that of 22 Cycle I and Cycle II study units for which data sets consisted of information from at least 15 wells.

The wells sampled by these study units make up large networks designated as major-aquifer studies (MAS); landuse studies (LUS), including the focused land-use studies in agricultural and urban regions; and source-water quality assessments (SWQA) of ground water used for public supplies. A smaller network consists of reference wells, which are primarily for monitoring background water quality. Because only two reference-network wells in this data set were sampled for fecal-indicator bacteria, that network was not included in this analysis. The large networks included wells that represented 16 of the 62 principal aquifers and aquifer systems described by the USGS Office of Ground Water in The National Atlas of the United States of America (U.S. Geological Survey, 2003). Total withdrawals from the 16 principal aquifers used for irrigation, public supply, and industrial purposes amounted to about 53,000 Mgal/d (Maupin and Barber, 2005). Seventy-six percent of these withdrawals were for irrigation purposes and 19 percent for public supplies. The water withdrawn from the High Plains principal aquifer in 2000 amounted to 17,500 Mgal/d (Maupin and Barber, 2005), the greatest amount of the 16 principal aquifers (table 1). The Central Valley, Calif., principal aquifer supplied the second highest amount of water $(9,800 \mathrm{Mgal} / \mathrm{d})$ (Maupin and Barber, 2005), which was used mostly for irrigation.

Table 1. Total estimated withdrawals of water from selected principal aquifers and withdrawals used for public supplies, irrigation, and self-supplied industrial in the United States, 2000.

[From Maupin and Barber, 2005. Abbreviations: Mgal/d, million gallons per day]

\begin{tabular}{lrccc}
\hline \multirow{2}{*}{$\begin{array}{c}\text { Principal aquifers and } \\
\text { aquifer systems }\end{array}$} & \multicolumn{4}{c}{ Withdrawals (Mgal/d) } \\
\cline { 2 - 5 } & Total & Public supplies & Irrigation & Industrial \\
\hline Columbia Plateau & 1,076 & 223 & 810 & 43 \\
Snake River Plain & 3,075 & 151 & 2,899 & 25 \\
Floridan & 3,640 & 1,330 & 1,930 & 385 \\
Piedmont-and-Blue Ridge & 175 & 110 & 30 & 35 \\
Basin-and-Range & 5,696 & 1,081 & 4,550 & 65 \\
Central Valley & 9,808 & 839 & 8,910 & 59 \\
Glacial Deposits & 3,553 & 1,950 & 1,020 & 583 \\
High Plains & 17,488 & 389 & 17,000 & 99 \\
Coastal Lowlands & 2,368 & 1,010 & 933 & 425 \\
Mississippi Embayment-Texas & 1,327 & 724 & 383 & 220 \\
$\quad$ Coastal Uplands & & & & \\
North Atlantic Coastal Plain & 1,035 & 793 & 70 & 172 \\
Ordovician & 5.8 & 4.8 & .6 & .4 \\
Valley-and-Ridge & 362 & 226 & 6.3 & 129 \\
Mississippian-Pennsylvanian & 418 & 289 & 12 & 117 \\
Southeastern Coastal Plain & 860 & 340 & 382 & 138 \\
Stream-and-River Valley & 1,800 & 456 & 1,190 & 154 \\
Denver Basin & 36 & 17 & 12 & 7.4 \\
Ozark Plateaus & 165 & 131 & 20 & 14 \\
\hline
\end{tabular}




\section{Microbial Indicators of Fecal and Sewage Contamination}

Direct analysis of pathogens in water is difficult and impractical (IAWPRC Study Group, 1991; Havelaar and others, 1993), but certain readily cultured bacteria, particularly the coliform and fecal streptococcus groups and bacteriophages (viral pathogens of bacteria), can be used as indicators of contamination. The total-coliform group is a broad group with several members of fecal and nonfecal origin. Over time, microbiologists have developed methods for analysis and enumeration of bacteria (Geldreich, 1966), such as the coliform species Escherichia coli (E. coli) and enterococci, that are specific for fecal contamination of water because they are consistently and nearly exclusively found in feces of warm-blooded animals (Cabelli, 1978; Gerba, 1987). The fecal-coliform group is a heat-tolerant subset of the total-coliform group and is differentiated in part by incubation at body temperature $\left(44.5^{\circ} \mathrm{C}\right)$ rather than at $35^{\circ} \mathrm{C}$, the temperature used to culture total coliforms. The fecalcoliform group is intermediate to the total coliforms and $E$. coli with respect to functioning as a fecal indicator because the test recovers species of nonfecal origin as well as $E$. coli and other fecal-origin coliforms. However, because the major species of the fecal-coliform group is E. coli (U.S. Environmental Protection Agency, 1978), the group has been extensively used for indicating fecal contamination (Geldreich, 1966). Some NAWQA studies included analyses for the fecalcoliform group, either in conjunction with, or in place of, the total coliforms.

The presence, or absence, of the total-coliform group has long been used for assessing drinking-water quality and has been written into water-quality standards promulgated as early as 1914 by the Public Health Service (McKee and Wolf, 1963). The coliform group, as defined by the American Public Health Association (APHA), is the principal indicator of the suitability of a water resource for domestic household or other uses. Although differentiation of the members of the coliform group, such as the fecal coliforms or E. coli, can be useful for evaluating a water resource for special study purposes, such as possible sources and types of contamination or how recent the contamination, the APHA considers the presence of any coliform bacteria in drinking water as unsatisfactory (American Public Health Association, 1998).

The U.S. Environmental Protection Agency (USEPA) regulates public drinking-water supplies through the Safe Drinking Water Act of 1974 (U.S. Environmental Protection Agency, 2003). USEPA's Total Coliform Rule of 1989 established maximum contaminant levels for total coliform bacteria, including fecal coliforms and E. coli, in publicsupply distribution systems and specified routine sampling requirements (U.S. Environmental Protection Agency, 2001a). The Total Coliform Rule also requires that if a sample of the finished (treated) water tests positive for total coliforms, the positive sample is tested for the presence of fecal coliforms or E. coli. The Ground Water Rule (U.S. Environmental Protection Agency, 2006) requires among other activities, disinfection of ground water "as necessary," sanitary surveys, and source-water monitoring.

The USEPA does not regulate the quality of water from privately owned, domestic wells used for drinking water. However, the agency provides a web site (http://www.epa. gov/safewater/privatewells/index $2 . \mathrm{html}$ ) at which private well owners can access an array of basic information and guidance on protecting their well water from contamination. USEPA also participates in a partnership of a number of other organizations, including Farm*A*Syst/Home*A*Syst, American Ground Water Trust, and the National Ground Water Association, that provide technical assistance and information for well owners.

Clostridium perfringens (C. perfringens) is a noncoliform species of bacteria that forms resistant spores that enhance survival of the organism outside of its normal habitat. The spores are resistant to sewage treatment processes and disinfection that readily kill members of the coliform group. C. perfringens is a useful fecal indicator in tropical climates and for tracking point sources of wastewater. The organism has been proposed as a surrogate for other spore-forming microorganisms such as Cryptosporidium that the traditional coliform groups might not adequately represent (Bisson and Cabelli, 1980)

Microorganisms of fecal origin are affected differently on entering the aquatic environment (Bisson and Cabelli, 1980; Havelaar and others, 1993), and no single indicator can address all concerns about the sanitary quality of the water (Cabelli, 1978). For ground water, enteric viruses are of particular concern because they are thought to be responsible for many infectious gastrointestinal illnesses related to the consumption of ground water (Borchardt and others, 2004). The U.S. Centers for Disease Control reported that during 2001-02, 23 of 25 non-Legionella outbreaks (92 percent) of drinking-water illnesses were linked to groundwater sources, and 5 of the 25 outbreaks ( 20 percent) were attributed to viruses (norovirus) (Blackburn and others, 2004). Bacteria, partly because of different survival rates, might be inappropriate for indicating the presence of viruses in water (Metcalf, 1978; Palmateer and others, 1991; 
Havelaar and others, 1993). Therefore, some researchers have suggested using the coliphage viruses (referred to as coliphage), particularly the male-specific coliphage (Gerba, 1987; Havelaar and others, 1993), and other bacteriophages as indicators of the potential presence of enteric viruses (DeBartolomeis and Cabelli, 1991; Havelaar and others, 1993; Sobsey and others, 1995).

The specific interest in the male-specific coliphage is their resemblance to human enteric viruses in morphology, genetic material, and similar resistance to environmental stresses and disinfection processes (Bitton, 1980; Sobsey and others, 1995). Coliphage infect cells of $E$. coli by attaching directly to the outer cell membrane (somatic coliphages) or to the F pilus of E. coli cells that contain the F plasmid (malespecific or F-specific coliphages) (International Association on Water Pollution Research and Control Study Group, 1991). Some organisms, such as the coliphages, appear to be specific indicators for sewage because they are consistently isolated in large, but variable numbers from sewage, and infrequently isolated or isolated only in low numbers from the feces of healthy individuals (Cabelli, 1978; Gerba, 1987; International Association on Water Pollution Research and Control Study Group, 1991). Studies conducted to show relations between the presence of enteric viruses with the presence of coliphage or the fecal-indicator bacteria in ground water supplies have reported mixed results (Francy and others, 2004). Some studies have shown a poor relation between the occurrence of enteric viruses and coliphage or with the fecal-indicator bacteria (Borchardt and others, 2003; Borchardt and others, 2004; Francy and others, 2004), and others have shown significant positive correlation between infectious total virus and the coliphage or total coliforms, E. coli, or enterococcus (Francy and others, 2004). Thus, the detection of coliphages in the NAWQA well samples does not indicate that pathogenic viruses also will be detected in the water; rather, the coliphage detection is more an indication of the potential for the transport of other viruses into the subsurface.

\section{Study Methods}

This section describes the establishment of the NAWQA study networks and the procedures used to select existing wells or construct new wells that were sampled for chemical and microbial quality. Procedures for the collection and handling of the ground-water samples, as well as the different microbiological analytical techniques used during the first and second cycles of the NAWQA program are described. Other parts of the section discuss quality assurance and quality-control procedures used for microbial-sample analyses and the statistics that were applied in the summaries of the microbiological data.

\section{Selection of Wells and Datasets Used in Analyses}

The selection or installation of wells for study networks followed NAWQA protocols that guide choosing site locations relative to land use, describe the suitability of existing wells with respect to plumbing and type of pump, and detail the construction of new monitoring wells regarding materials and drilling methods to meet the program's study objectives (Scott, 1990; Koterba and others, 1995; Lapham and others, 1995). Selection of wells for the SWQA networks followed NAWQA guidelines described by Gregory Delzer (U.S. Geological Survey, written commun., June 2002, rev. March 2003).

The water from these wells is used for various purposes, including irrigation, stock watering, and recreation, as well as domestic and public drinking-water supply. Water use is designated as "unused" or "test" for wells used only for monitoring purposes such as water-level or water-quality measurements.

Within 27 study units, samples were collected from 1,244 wells in 16 principal aquifers of the United States. Through combinations of well networks (MAS, LUS, SWQA), most study units sampled more than 20 wells; however, the numbers sampled ranged from 2 wells in the Red River of the North (REDN) to 155 in the Lower Susquehanna (LSUS) (table 2). From the 1,244 wells, 1,784 samples (including replicate samples for quality control) were analyzed for concentrations of fecal-indicator bacteria and the presence or absence of coliphages. Field measurements of water temperature, $\mathrm{pH}$, specific conductance, and concentrations of dissolved oxygen were taken at the time of sample collection. Water samples were analyzed for a broad range of constituents including nutrients, major ions, trace elements, and pesticides.

For describing the microbial quality of the Nation's ground-water resources, 15 wells in each study unit were considered to be the minimum for representing or describing the quality of the ground water of a region or a principal aquifer. Therefore, data for individual study units that sampled less than 15 wells total from all their networks were removed from this analysis. This criterion reduced the number of study units from 27 to 22 and the number of wells sampled from 1,244 to 1,205 . The five study units removed from the data set were Apalachicola-Chattahoochee-Flint (ACFB), AlbemarlePamlico (ALBE), Ozark Plateaus (OZRK), Red River of the North (REDN), and South Platte (SPLT) (table 2). 
Table 2. Principal aquifers, primary lithology of the aquifers, well-sampling networks within each study unit, and the total number of wells sampled during water years 1993-2004.

[Study unit: ACAD, Acadian; ACFB, Apalachicola-Chattahoochee-Flint; ALBE, Albemarle-Pamlico; CCYK, Central Columbia Plateau-Yakima; CONN, Connecticut; DELR, Delaware; GAFL, Georgia-Florida; HPGW, High Plains; KANA, Kanawha; LERI, Lake Erie; LSUS, Lower Susquehanna; MOBL, Mobile; NVBR, Nevada basin and range; OZRK, Ozark Plateaus; PODL, Potomac-DelMarva; PUGT, Puget Sound basin; REDN, Red River of the North; SANJ, San Joaquin; SANT, Santee; SPLT, South Platte; TENN, lower and upper Tennessee; TRIN, Trinity; UCOL, upper Colorado; USNK, Upper Snake River; WHMI, White-Miami; WMIC, Western Lake Michigan; YELL, Yellowstone. Study networks: MAS, major aquifer study; SUS, study unit survey (during Cycle I; equivalent to Cycle II MAS); SWQA, source-water quality assessment; LUS, land-use study; CR, cropland; AG, agriculture; UR, urban; RS, residential; RC, new residential/commercial; MI, mining; REF, reference; FPS, flow-path study. Lower case letters and numbers following study network indicate study unit or NAWQA network coding]

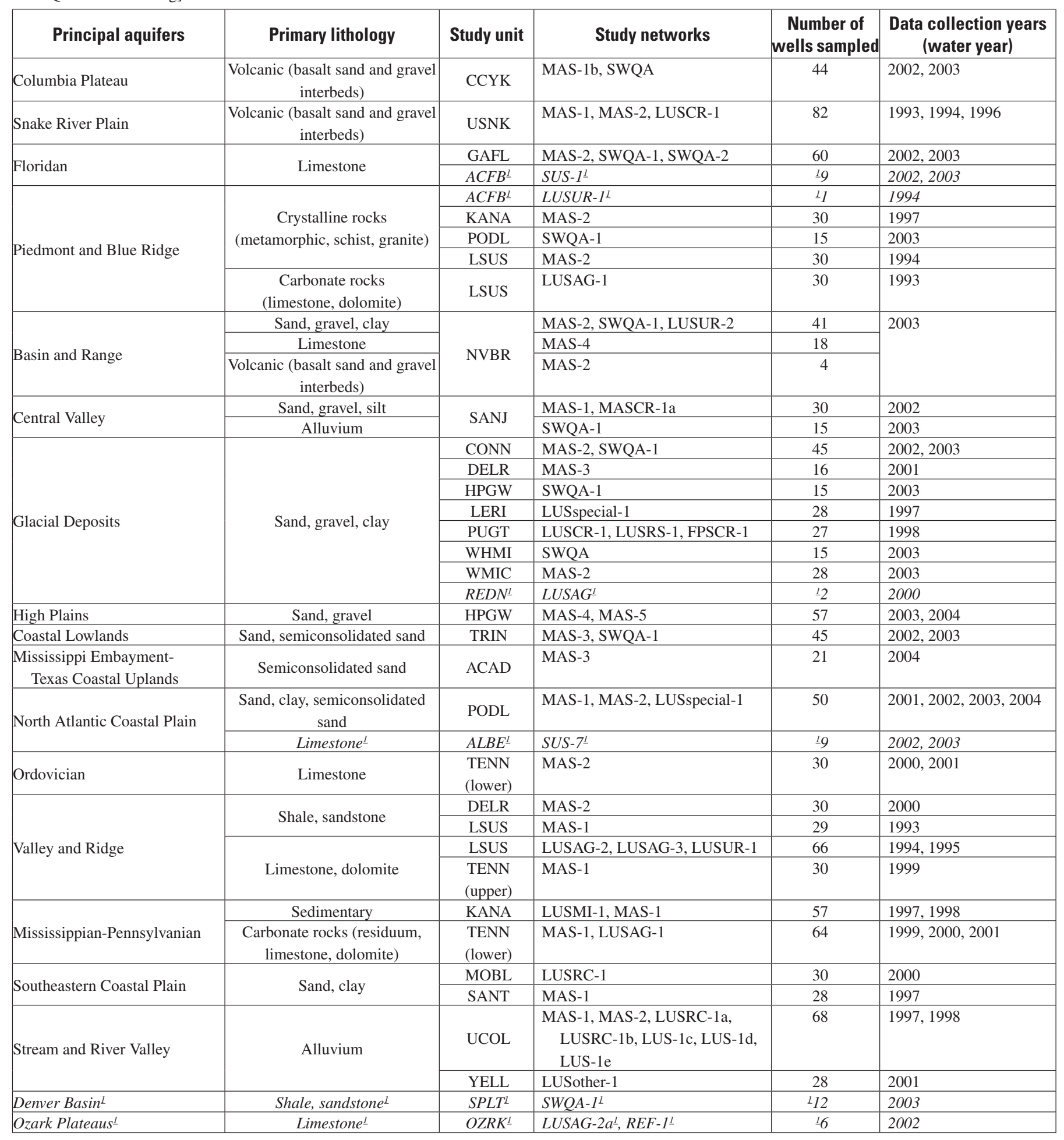

${ }^{1}$ Study unit, well-sampling network, and wells not included in final analyses of this report. 


\section{Sample Collection and Measurements}

The collection, handling and processing, and laboratory analyses of the samples, and field measurements made during their collection, followed USGS protocols and the guidelines of the NAWQA program during the early years of Cycle I (Koterba and others, 1995). The USGS National Field Manual (NFM), which in the late 1990s consolidated numerous guidance documents, technical memoranda, and sampling protocols, became the primary guide for the collection of water-quality data in the USGS. Chapters A1-A6 of the NFM guide the selection and cleaning of equipment, the collection and processing of water samples, and methods of measurements performed in the field (U.S. Geological Survey, variously dated); chapter A7 specifically guides the collection and processing of water for biological indicators (Myers and Wilde, 2003).

All equipment used in the collection and processing of water samples for microbiological analyses was thoroughly cleaned with laboratory-grade detergent followed by several rinses with deionized or reagent-grade water. Following the cleaning, all equipment for microbiological sampling and processing was sterilized before use by means of steam heat and pressure (autoclaving) or chemical disinfection (bleach or alcohol). Exceptions to autoclaving or chemical disinfection might apply to the submersible pumps used to collect water from monitoring wells (wells without an in-place pump). The cleaning of submersible pumps and sample tubing along with recommendations for additional quality-control samples are documented in chapter A7 of the NFM (U.S. Geological Survey, variously dated). Depending on the study network, wells selected for study were existing wells with in-place pumps and in use for domestic or public supply, or for purposes such as irrigation and livestock watering; or unused wells with or without an in-place pump. These different types of wells and conditions call for slightly different techniques for obtaining water to test for chemical or microbiological constituents.

Water samples were collected at a point as close as possible to the well head, thereby avoiding the effects of distribution lines, pressure tanks, filtration, or other treatment. Thus, the microbiological and other water-quality data reported here represent analyses of raw, untreated water only. None of these data resulted from analyses of treated finished water from distribution systems or at the point of use. As the water was withdrawn from the wells, temperature, $\mathrm{pH}$, specific conductance, and concentrations of dissolved oxygen were monitored until stable values of these properties indicated that aquifer water had replaced "old," standing water within the well casing. On reaching stable conditions, final readings of the field measurements were recorded and sterile samplecollection bottles were filled for subsequent microbiological analyses.

\section{Microbial Analyses and Sources of Data}

Water samples for analyses of most fecal-indicator bacteria were processed within 6 hours of collection. Samples for the analyses of coliphage or $C$. perfringens were shipped to the USGS Ohio Water Microbiological Laboratory (OWML) within 24 hours of collection or on the same day of collection to meet the laboratory's hold time criterion of 48 hours to the start of analysis (Bushon and others, 2003).

The samples were analyzed for fecal-indicator bacteria using membrane-filtration methods, which involve filtering known volumes of sample water through a membrane filter, placing the filter on a Petri dish of growth medium, and incubating the dish for a specified length of time and temperature. After incubation, colonies of target organisms on the filter were counted and converted to a concentration expressed in terms of numbers of organisms per $100 \mathrm{~mL}$ of sample. During the first cycle of the NAWQA program, long-established methods commonly employed were for the total-coliform group on mENDO medium (method 9222B, American Public Health Association, 1992); the fecal-coliform group on mFC medium (method 9222D, American Public Health Association, 1992); E. coli on nutrient agar with 4methylumbelliferyl- $\beta$-D-glucuronide (NA-MUG) medium (method 9222G, American Public Health Association, 1992) or on mTEC medium (method 1103.1, U.S. Environmental Protection Agency, 2002a); and the fecal streptococcus group on mKF medium (American Public Health Association, 1992; Britton and Greeson, 1988). During Cycle I, investigators in some study units also collected samples for analysis of concentrations of enterococci bacteria on mE/EIA media (method 1106.1, U.S. Environmental Protection Agency, 2002b) and C. perfringens, which were determined at the OWML using membrane-filtration on $\mathrm{mCP}$ substrate as described in the Information Collection Rule microbial laboratory manual (U.S. Environmental Protection Agency, 1996).

As approved methods using new growth media and culturing techniques became available during the Cycle II phase of studies, the NAWQA program adopted those methods for analysis of fecal-indicator bacteria and viruses in ground water. The new methods included use of the single-growth medium for simultaneous recovery of the total coliforms and E. coli on MI medium (method 1604, U.S. Environmental Protection Agency, 2002c) in the field. At the OWML, updated methods included testing for the presence or absence of somatic and male-specific coliphages by the 2-step enrichment procedure (method 1601, U.S. Environmental Protection Agency, 2001b).

The fecal-streptococcus, enterococci, and $C$. perfringens data were included as part of the inventory of data (fig. 2), but they are not part of the discussion of the quality of water in principal aquifers or drinking-water supplies because of 


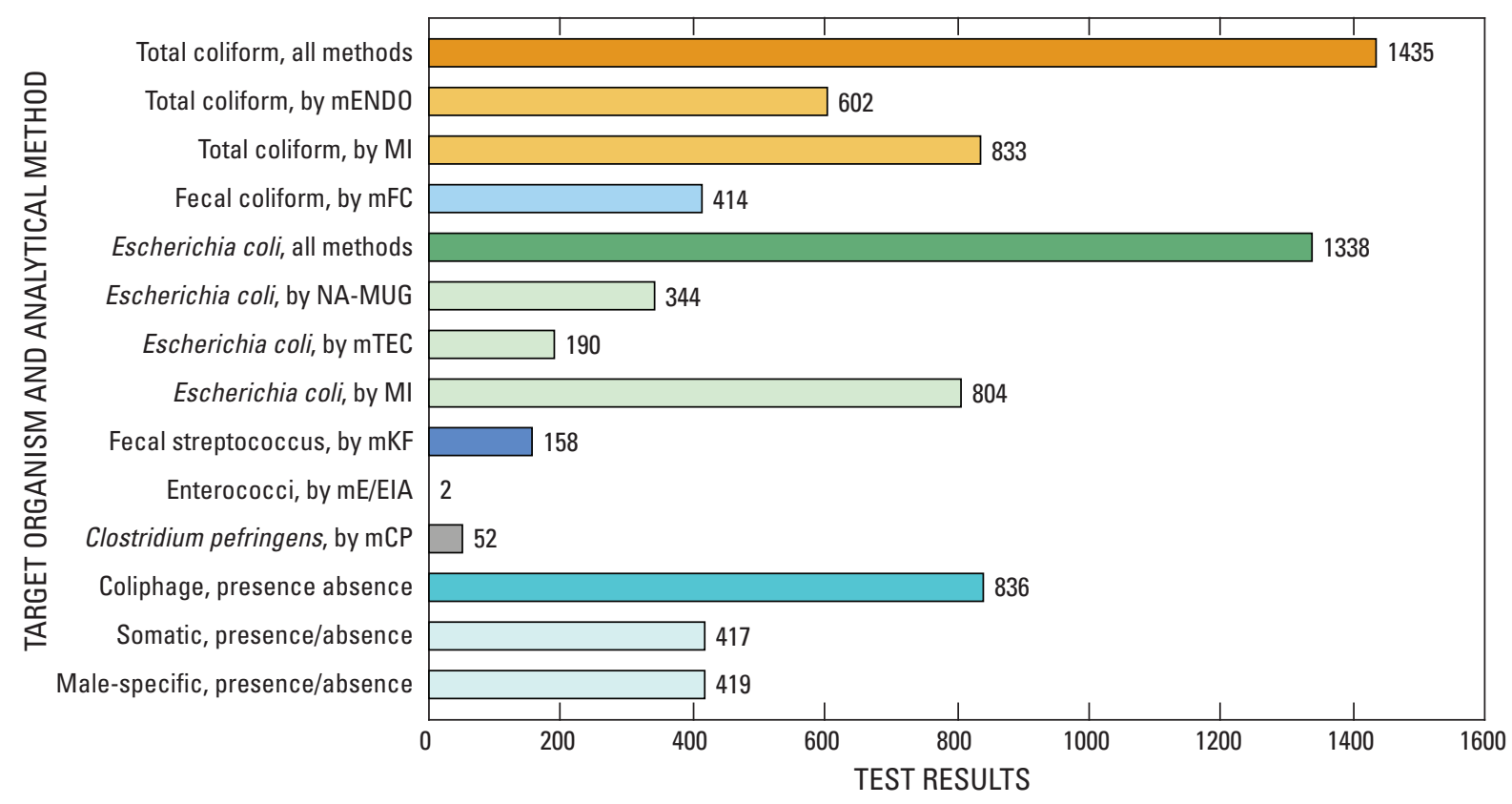

Figure 2. Numbers of test results for fecal-indic ator microorganisms by each analytical method for environmental and quality-control samples collected from wells in 22 study units of the National Water-Quality Assessment program, 1993-2004.

the small number of tests. In the final data set that included replicate quality-control samples for the 22 study units, 1,435 analytical results for the total-coliform group, 1,338 for E. coli, and 836 for coliphage were available for assessing the occurrence of fecal-indicator bacteria and virus in ground water of different principal aquifers (fig. 2). The water from these aquifers was used for various purposes.

Microbiological data collected for the NAWQA program and ancillary data including chemical analyses and well characteristics can be accessed from the USGS National Water Information System (NWIS) data base (http://waterdata. usgs.gov/nwis), the Data Warehouse (http://infotrek.er.usgs. gov/traverse/f?p=NAWQA:HOME:9108424999420775073), or individual study units (http://water.usgs.gov/nawqa/).

The raw data were simplified and consolidated to create, to the extent possible, a consistent and comprehensive final data set by study unit, by sampling network, and by principal aquifer (table 3). For example, water samples collected from wells in the Snake River aquifer in the Upper Snake study unit (USNK) were analyzed for only the fecal-coliform group. To include discussion of the Snake River aquifer in conjunction with other principal aquifers, the results for USNK, with all but one sample testing negative for fecal coliforms, were compared to E. coli results on the basis that the predominant member of the fecal coliform group is the species E. coli (U. S. Environmental Protection Agency, 1978). Some actions involved assigning a well to a principal aquifer or to a dominant lithology. These actions were based on several sources, including ancillary information available in the USGS data bases, the geographic location of the wells and study units overlaid on the national maps of principal and major aquifers, and the primary lithologies of the principal aquifers as assigned by the NAWQA Principal Aquifer regional assessment teams (Wayne W. Lapham, U.S. Geological Survey, written commun., 2005).

Another consolidation of data involved reducing analyses of multiple samples collected at a well to a single analytical result so that statistical summaries for all study units and principal aquifers were equally weighted on the basis of a single value (table 3). These reductions involved data collected in the High Plains Ground Water (HPGW), Kanawha (KANA), Potomac-Delmarva (PODL), Puget Sound Basin (PUGT), Upper Colorado (UCOL), USNK, and lower and upper Tennessee (TENN) study units. One approach to data consolidation was to select data for a group of wells, such as a study network, collected during a particular period, and reject samples for the same wells collected outside that period. The selected period was chosen to maximize numbers of wells and reported results for the study unit or principal aquifer. Another approach was to select the data that represented the first visit and sampling of a well in a particular network. The first visits to wells often equated to the greatest number of wells and 
Table 3. Consolidations and adjustments to the raw microbiological and associated ground-water data by study unit and network, water use, principal aquifer, and lithology.

[Abbreviations: CCYK, Central Columbia Plateau-Yakima; CONN, Connecticut; GAFL, Georgia-Florida; HPGW, High Plains; KANA, Kanawha; PODL, Potomac-DelMarva; PUGT, Puget Sound Basin; SANJ, San Joaquin; TENN, lower and upper Tennessee; TRIN, Trinity; USNK, Upper Snake River; WMIC, Western Lake Michigan; MAS, major aquifer study; SWQA, source-water quality assessment]

\section{Adjustments made to reduce multiple observations at} an individual well to a single representative value

\section{HPGW:}

Removed 1 of 2 samples in June 2004 and retained the sample with an analysis of coliphage virus

\section{KANA:}

Removed 1 of 2 pairs of samples (multiple quality-control samples) from 1 well

\section{PODL:}

Removed 1 sample in 2004 from 1 well and retained the earlier 2001 sample, which was part of a larger set of results

PUGT:

Removed the August 1998 samples and retained the March 1998 samples, which were part of larger sets of results for two land-use study networks.

\section{CCYK:}

Removed the October 1997 samples and retained the first set of samples collected in March-April 1997 for an urban land-use study network.

\section{USNK:}

For 42 of 82 wells in 1994 and 1995, retained the August monthly samples, some of which had corresponding chemical analyses.

\section{TENN:}

Removed a 2001 sample from 5 wells and retained the 2000 samples, which were part of a larger set of data

\section{Adjustments and assumptions taken to populate} selected data fields with missing values

\section{CCYK:}

For the SWQA network, principal aquifer assumed to be Columbia Plateau and primary lithology as volcanic (basalt)

\section{CONN:}

Lithology assumed to be sand or sand and gravel

\section{GAFL:}

For wells listed as cased test hole, assumed to be unused; lithology assumed to be limestone

SANJ:

For SWQA, lithology assumed to be alluvium

\section{TRIN:}

For some MAS-3 network wells, lithology assumed to be sand

\section{USNK:}

Lithology for 3 wells assumed to be basalt/volcanic and for 1 well, sand and gravel

\section{WMIC:}

Lithology for 2 wells assumed to be sand and gravel samples for a study network. In addition, for discussing the quality of ground water by network, water use, or principal aquifer, only one result from the pair of samples was used. Therefore, if one of the pair tested negative and one tested positive for the target organism, the entire well was considered to test positive for that organism.

Because of quality-control issues, some analytical results for the coliform bacteria and coliphage were excluded from the final data set. No coliphage samples collected from wells in the KANA, Lake Erie (LERI), Santee (SANT), and UCOL study units during 1997-98 and analyzed by quantitative methods were used in this report.

\section{Quality Assurance and Quality Control}

Prior to water-year 2003, quality-assurance (QA) procedures and the collection or preparation of quality-control (QC) samples generally followed the guidelines presented in Britton and Greeson (1988) and Myers and Sylvester (1997).
Those guidelines suggest that at a minimum, QC samples should include processing filter blanks-one blank at the beginning of filtration (an equipment blank) and one blank at the end of filtration (a procedure blank), bracketing the processing of a water sample. The guidelines also specified the use of heat-sensitive indicator tape on all autoclaved sample-collection and filtration equipment for monitoring the effectiveness of the autoclave and ensuring sterilization of equipment.

In water-year 2003, when the NAWQA program incorporated microbiology as part of routine sampling schedules for Cycle II, additional guidelines that list the types of QA procedures and numbers of QC samples appropriate for the NAWQA program were put in place (http://oh.water.usgs. gov/micro/nawqa.html). For fecal-indicator bacteria in ground water, the guidelines specify a pair of samples be collected at each well and a set of filter blanks be processed to accompany every pair of water samples. The filter blanks document sterility of the filtration equipment, lack of carryover of cells 
between filtrations, and whether cells are lost to the walls of the filtration equipment due to incomplete rinsing. The guidelines also specify processing of field blanks and of positive and negative control samples at frequencies depending on numbers of wells sampled. Processing of field blanks involves passing sterile water through all parts of collection equipment, from the pump (if applicable) through the tubing and into the sample bottles. Positive and negative control samples are pure cultures of target organisms that ensure the quality of media and reagents for use. The control samples are processed by the membrane filtration method and the results are evaluated for proper recovery and growth of the positivecontrol organism and lack of growth by the negative-control organism. In addition to the QC samples for the fecal-indicator bacteria, field blanks are prepared for coliphage analysis, and replicate samples are collected and spiked with target organisms at the laboratory to determine if there are matrix interferences in the analysis.

At the time of this data compilation, selected QC data were obtained from nine Cycle II study units for evaluating the set of microbiological data for the purposes of this report. QC data were not requested from the Cycle I study units because these data do not exist in electronic data bases and so are not easily constructed from archived files. For the Cycle II data, target organisms were detected in only 13 of 379 filter blanks (3.4 percent). For the individual study units reporting filter-blank data, detection rates ranged from 1 to 12 percent of the blanks prepared. The QC guidelines state that if target colonies in the filter blank are less than 5 percent of the colony count of the environmental sample, the results for the sample are accepted. If target colonies on the filter blank are greater than 20 percent of the target colonies of the sample, the results are rejected. For target colonies that amount to 5 to 20 percent of a sample's colony count, the concentration value in NWIS is assigned a remark code of V (value affected by contamination), a value-qualifier code of $\mathrm{W}$ (high variability), and a result-level comment indicating the number of target colonies in the filter blank. Evaluation of the filter blank data resulted in rejecting five sample results (including any replicates) for the total coliform group. During their wellnetwork sampling, five Cycle II study units processed field blanks, all of which were negative for target organisms. Analyses of these filter- and field-blank samples indicated that equipment sterilization, sampling procedures, and sample handling and filtration were effectively controlled and thus resulted in a set of high-quality data for describing the quality of the ground-water resources.

NAWQA staff in eight of the Cycle II study units consistently collected and processed duplicate samples for each well. The relative percent differences in the analytical results for 402 pairs of samples ranged from 0 to 200 percent.
The average and median relative percent differences were 13 and 0 , respectively. Most pairs (338) had the same value, which results in percent differences of zero.

\section{Statistical Analyses}

Graphical analyses of the data set through the use of box plots, notched box plots, scatter plots, and bar charts were used to evaluate the occurrence, distribution, and potential relations of the fecal-indicator bacteria in ground water with other constituents or with well characteristics. Box plots display summaries of the distribution of a group of data by showing the center location (median), the variation through the height of the box (interquartile range of values), the skewness through the relative size of the box halves, and extreme values or outliers of the data (Helsel and Hirsch, 1992). Notched box plots portray the same information and also show the 95-percent confidence interval about the median. Boxes with nonoverlapping notches indicate significant differences between the groups of observations (McGill and others, 1978). Scatter plots can indicate patterns in a group of data, such as correlation or trend relations. Bar charts are mostly used in this report to display numbers of observations or frequencies of bacterial detections.

Nonparametric statistical testing by the Kruskal-Wallis test and Wilcoxon rank-sum test was used to examine the data for significant differences between groupings of coliform bacteria concentrations or detections within study networks, classes of water use, principal aquifers, or types of lithology. The null hypothesis of the Kruskal-Wallis test states that the rank of the median (or mean) of the data for each group is identical, and the alternative hypothesis is that at least one group differs in its distribution, which tends to produce observations (concentrations) different in value (Helsel and Hirsch, 1992). The Kruskal-Wallis test does not determine which group or groups are different. For this, the Wilcoxon rank-sum test was used with significance levels adjusted for the total number of tests performed within each group of data, or notched box plots helped to identify statistically different groups within the groupings of interest.

For statistical testing of concentration data, values reported as < (less than) $1 \mathrm{CFU} / 100 \mathrm{~mL}$ (colony forming unit per 100 milliliters) in the USGS NWIS database were treated as zeroes. This assumption was because no organisms were found on the filter and media; therefore the count for that test was zero organisms. Statistical tests were also performed with coliform bacteria data expressed as detections (with positive results set to equal 1) or nondetections (with negative results set to equal 0), and with coliphage data, which are coded in NWIS as a 1 (for present in the sample) or a 2 (for absent in the sample). 
Microbial Quality of Water in Principal Aquifers

Testing was done for fecal-indicator bacteria and coliphages on samples from at least 15 wells in the 22 study units during Cycle I or Cycle II of the NAWQA program. Concentrations and detection frequencies of fecal-indicator bacteria and coliphage are summarized by study networks and by principal aquifers and their lithology. The occurrence of these microorganisms in water supplies and relations to selected well and water-quality characteristics are also discussed.

The 22 study units collected samples from 1,205 wells as part of the MAS, LUS, and SWQA sampling networks. Concentrations of fecal-indicator bacteria in 1,174 of these wells were used in the analyses described in this report. Samples collected from 450 wells in 11 of the 22 study units were analyzed for the presence of coliphage. Coliphage data from 423 of those wells were available for this analysis.

The study wells are completed in 16 principal aquifers and 7 types of lithology. Water-use types for these wells were originally coded by study-unit staff within 1 of 15 categories, including drinking-water supply (domestic or public), water used for power or aquaculture, and water use designated as "other" or "unused." For this report, several of the minor types of water use were combined-commercial, industrial, institutional, and recreational into one class; irrigation and stock watering into a second class; and a third class referred to simply as "other." Water-use types described in this report include these three combined classes and the classes termed domestic, public, and unused.

Detection frequencies and concentrations of totalcoliform bacteria were significantly different ( $\mathrm{p}$-value $<0.05$ ) among the study networks, principal aquifers, types of lithology, and water-use classes. These differences are further examined in the discussions of the microbial quality of ground water sampled for the NAWQA program.

\section{Fecal-Indicator Bacteria and Coliphage Viruses in Study-Unit Well Networks and Principal Aquifers}

Fecal-indicator bacteria were geographically widespread, with at least one well testing positive among all the wells sampled within each study unit and principal aquifer (fig. $3 A$ and $\underline{3 B}$ ). Coliphage, which occur less frequently than the bacteria, were present in well samples from 4 of the 11 study units that sampled and tested for coliphage- the Central Columbia Plateau-Yakima (CCYK), Georgia-Florida (GAFL), San Joaquin (SANJ), and Trinity (TRIN) study units, representing the Columbia Plateau, Floridan, Central Valley, and Coastal Lowlands aquifers, respectively.

Samples from 347 wells (29.6 percent of the 1,174 wells for which data were used in this analysis) tested positive for fecal-indicator bacteria (either total coliform, E. coli, or fecal coliform). Individual study-unit detection frequencies ranged from 1 out of 82 well samples (1 percent) in the USNK testing positive for fecal coliforms to 108 out of 155 samples (70 percent) in the LSUS testing positive for total coliforms (fig. 4). The greatest number of wells that tested positive for $E$. coli was in the TENN study unit; 32 out of 124 wells (26 percent) tested positive.

Concentrations of total coliforms in samples from the 1,174 wells ranged from $<1$ to $1,600 \mathrm{CFU} / 100 \mathrm{~mL}$ and concentrations of $E$. coli ranged from $<1$ to 1,200 CFU/ $100 \mathrm{~mL}$. Median concentrations for both total coliforms and E. coli were at the reporting limit of $<1 \mathrm{CFU} / 100 \mathrm{~mL}$. In addition, 67 percent of total coliform and 85 percent of $E$. coli concentrations were at the minimum reporting limit, indicating that most concentrations are low.

With 61 percent of all the wells sampled, the MAS is the largest of the three major study networks, followed by the LUS network and the SWQA network (table 4). For the MAS, totalcoliform concentrations for 566 wells; $E$. coli concentrations for 592 wells; and coliphage results for 280 wells were used in this analysis (table 4). For the LUS network, concentrations of total coliforms and $E$. coli were available for 251 wells and 237 wells, respectively. For all three networks, the highest percentage of total coliform detections (50.2 percent) occurred in wells in the LUS network, and in the agricultural LUS network, total coliforms were detected in 67.2 percent of the wells (fig. 5A). In contrast with the LUS network, the lowest percentage of total-coliform detections (19.5 percent) occurred in wells in the SWQA network. Median concentrations of coliform bacteria were $<1 \mathrm{CFU} / 100 \mathrm{~mL}$ for the MAS and SWQA networks, $1 \mathrm{CFU} / 100 \mathrm{~mL}$ for the LUS network, and $4 \mathrm{CFU} / 100 \mathrm{~mL}$ for the agricultural LUS network. Excluding the high concentration of coliform bacteria in a sample from one well, total coliform concentrations were equal to or less than $420 \mathrm{CFU} / 100 \mathrm{~mL}$ and $E$. coli concentrations were equal to or less than $440 \mathrm{CFU} / 100 \mathrm{~mL}$ (fig. $5 \mathrm{~B}$ ). 


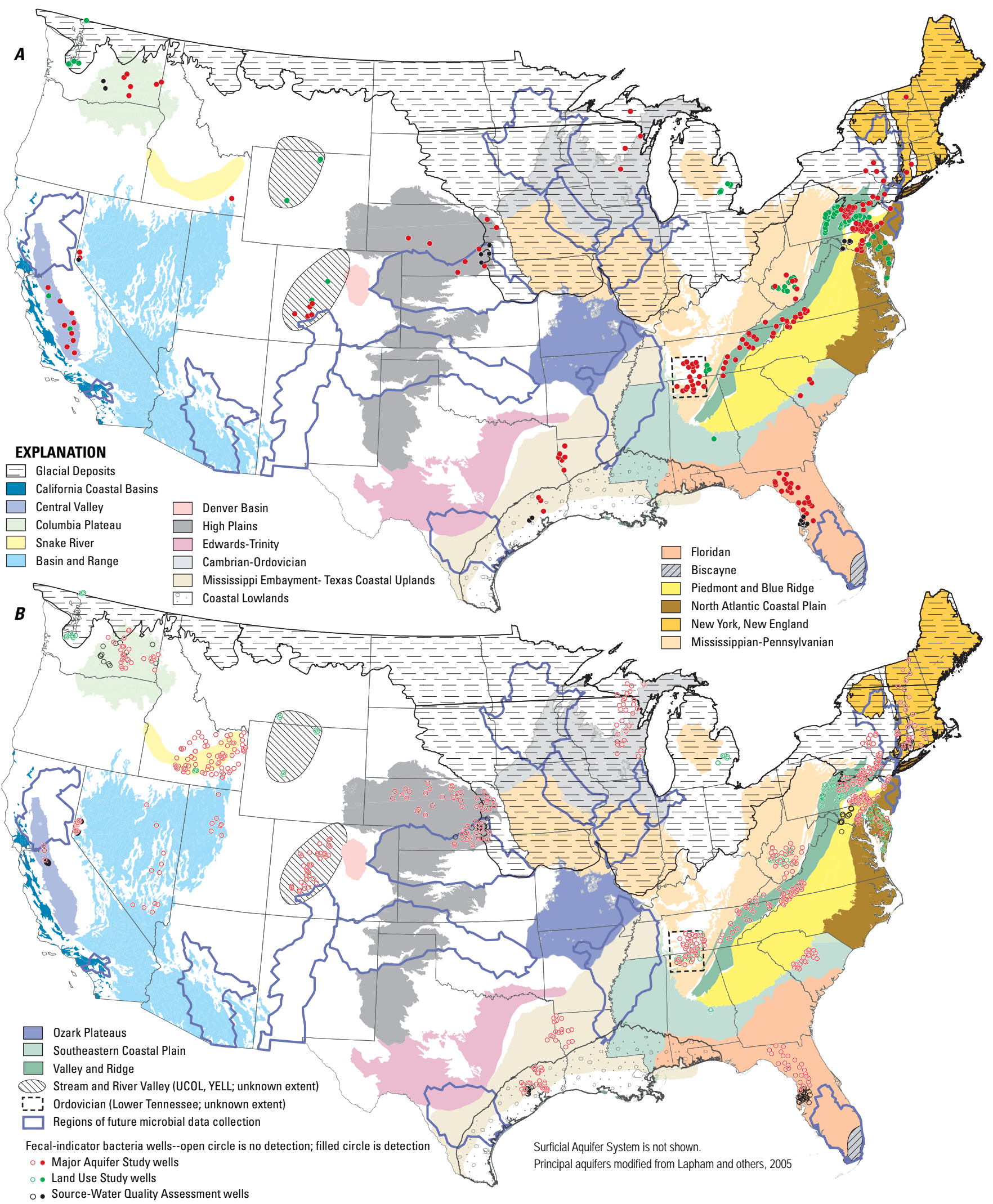

Figure 3. Locations of wells in principal aquifers that tested positive for fecal-indicator bacteria $(A)$ and wells where fecalindicator bacteria were not detected in samples collected for the National Water-Quality Assessment program (B), 1993-2004. 


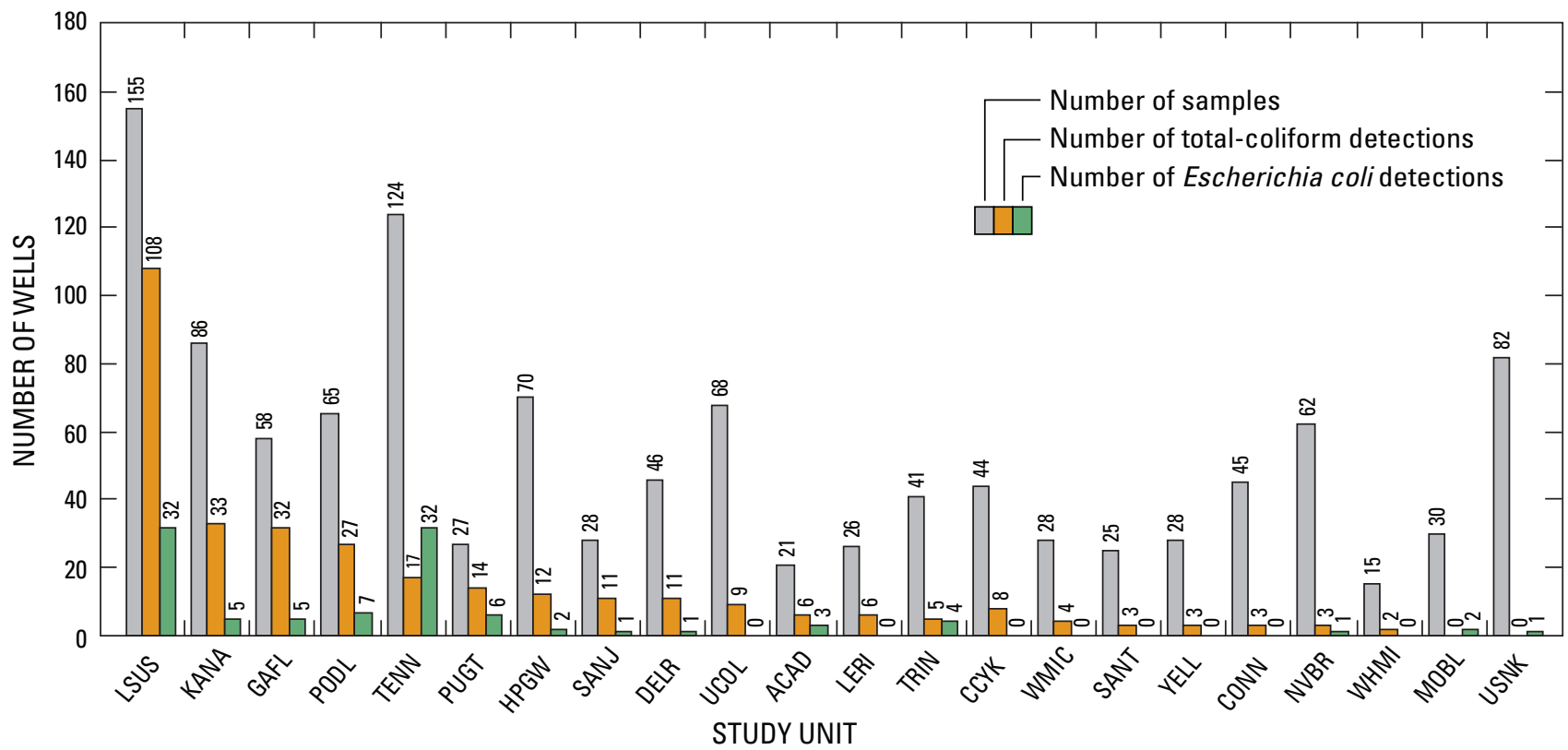

Figure 4. Number of wells sampled and number of wells with detections of coliform bacteria in samples collected in 22 study units of the National Water-Quality Assessment program, 1993-2004. (See table 2 for explanation of study-unit name abbreviations.)

Table 4. Summary of microbiological data collected from wells in major aquifer study, land-use study, and source-water quality assessment networks in 22 study units of the National Water-Quality Assessment Program, 1993-2004.

[Study network: MAS, major-aquifer study; LUS, land-use study; SWQA, source-water quality assessment. Abbreviations: CFU/100mL, colony-forming units per 100 milliliters. Symbols: <, less than; >, greater than; -, no value]

\begin{tabular}{|c|c|c|c|c|c|}
\hline \multirow[t]{2}{*}{ Tests } & \multirow[t]{2}{*}{ Study network } & \multirow{2}{*}{$\begin{array}{l}\text { Number } \\
\text { of wells }\end{array}$} & \multirow{2}{*}{$\begin{array}{l}\text { Number of wells } \\
\text { with detections } \\
\text { (percentage) }\end{array}$} & \multicolumn{2}{|c|}{$\begin{array}{c}\text { Concentration } \\
\text { (CFU/100mL) }\end{array}$} \\
\hline & & & & Median & Range \\
\hline \multirow[t]{5}{*}{ Total coliform } & MAS & 566 & $162(28.6)$ & $<1$ & $<1-1,600$ \\
\hline & LUS, all & 251 & $126(50.2)$ & 1 & $<1-420$ \\
\hline & LUS, agriculture & 119 & $80(67.2)$ & 4 & $<1->80$ \\
\hline & LUS, urban & 77 & $27(35.1)$ & $<1$ & $<1-\quad 110$ \\
\hline & SWQA & 149 & $29(19.5)$ & $<1$ & $<1-\quad>80$ \\
\hline \multirow[t]{5}{*}{ Escherichia coli } & MAS & 592 & $51 \quad(8.6)$ & $<1$ & $<1-1,200$ \\
\hline & LUS, all & 237 & $50(21.1)$ & $<1$ & $<1->80$ \\
\hline & LUS, agriculture & 112 & $34(30.4)$ & $<1$ & $<1->80$ \\
\hline & LUS, urban & 70 & $12(17.1)$ & $<1$ & $<1->80$ \\
\hline & SWQA & 149 & $3 \quad(2.0)$ & $<1$ & $<1-$ \\
\hline \multirow[t]{5}{*}{ Coliphage } & MAS & 280 & $9 \quad(3.2)$ & - & - \\
\hline & LUS, all & 3 & $0 \quad(0)$ & - & - \\
\hline & LUS, agriculture & 2 & $0 \quad(0)$ & - & - \\
\hline & LUS, urban & 1 & $0 \quad(0)$ & - & - \\
\hline & SWQA & 140 & $5 \quad(3.6)$ & - & - \\
\hline
\end{tabular}

${ }^{1}$ Includes Upper Snake River (USNK) wells sampled for fecal coliforms. 
$\boldsymbol{A}$

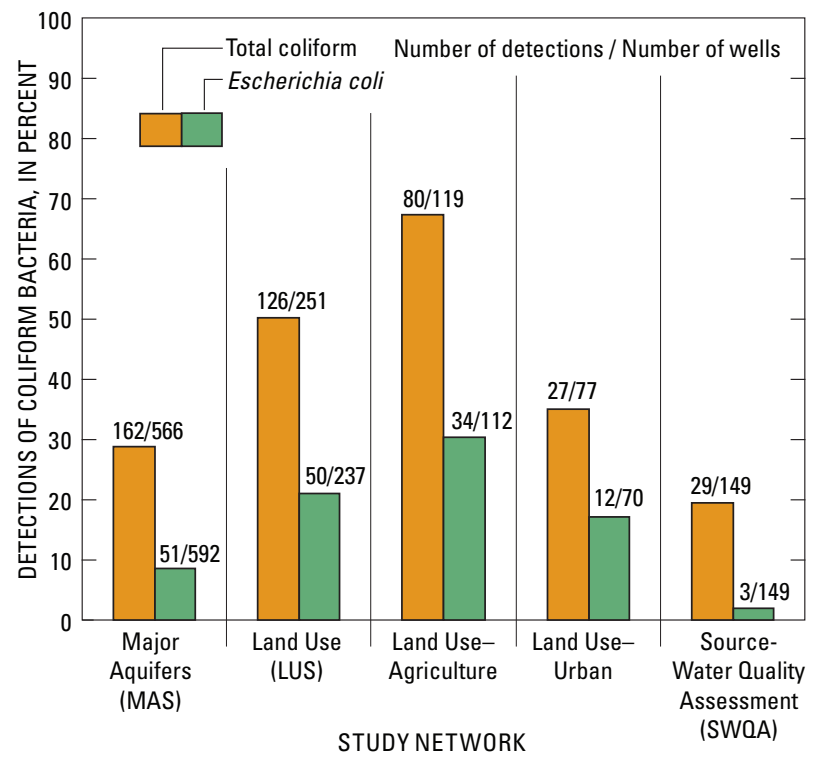

$B$

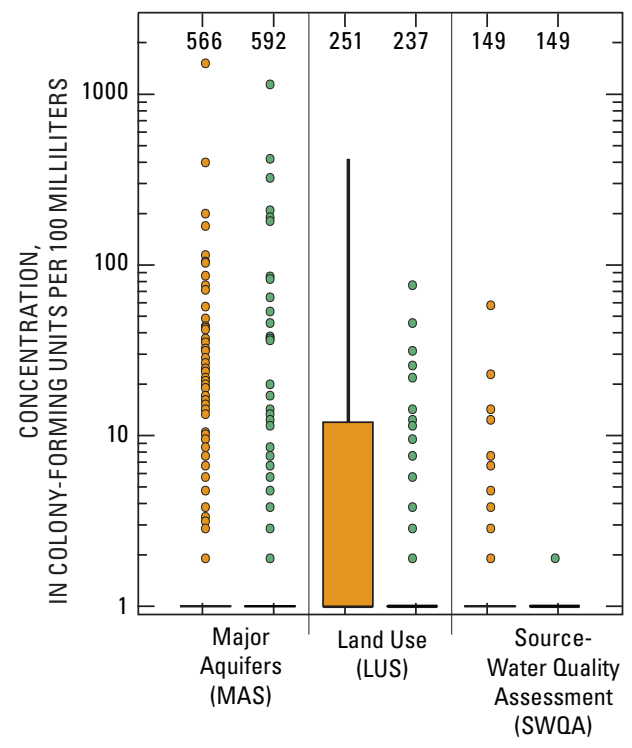

EXPLANATION

SCHEMATIC BOXPLOT

566 Number of values

- Upper detached

$x$ Upper outside

$1.5 \mathrm{X}$ interquartile
range

range
75 th percentile

Median

25th percentile

$1.5 \mathrm{X}$ interquartile range

$x$ Lower outside

- Lower detached

$\square$ Total coliform

$\square$ Escherichia coli

Figure 5. Percentage of wells testing positive for total coliform bacteria and Escherichia coli $(A)$, and concentrations of coliform bacteria $(B)$ by study network in samples collected in 22 study units of the National Water-Quality Assessment program, 1993-2004.

Of the 16 principal aquifers studied by the NAWQA program during 1993-2004, the number of wells testing positive for coliform bacteria exceeded 50 percent in three aquifers - the Valley and Ridge, Floridan, and the Piedmont and Blue Ridge (fig. $6 \mathrm{~A}$ and table 5). The lowest detection frequencies of coliform bacteria (less than 5 percent) among the 16 principal aquifers were in samples from wells in the Basin and Range and Snake River aquifers (fig. 6A, table 5). Detection frequencies of total coliform bacteria for the Valley and Ridge, Floridan, and Piedmont and Blue Ridge aquifers were significantly higher ( $\mathrm{p}$-value $<0.0006$ ) than detection frequencies for the Glacial Deposits, Columbia Plateau, High Plains, Stream and River Valley, Coastal Lowlands, Southeastern Coastal Plain, and Basin and Range aquifers (fig. 6B).

For the large MAS network, the frequency of wells testing positive for total coliform was 82 percent for the Central Valley aquifer (fig. 7A); however, this high frequency of detection might be a function of the low number of available samples. Detection frequencies of $E$. coli were highest for MAS wells in the Ordovician aquifer (30 percent), followed by detections in the Central Valley (25 percent) and the Mississippian-Pennsylvanian (19 percent) aquifers (fig. 7A).
The Piedmont and Blue Ridge, Floridan, Coastal Lowlands, Columbia Plateau, Glacial Deposits, Basin and Range, and Central Valley aquifers, or just less than one-half the 16 aquifers studied since 1993, were the first principal aquifers to be sampled as part of the new SWQA network of NAWQA Cycle II. Samples with the highest detection frequencies of total coliforms were collected from Piedmont and Blue Ridge wells (greater than 50 percent) followed by detections in samples from wells completed in the Floridan aquifer (30 percent). Detection frequencies of $E$. coli were low, however, with nondetections reported for all wells in 4 of the 7 aquifers and only one detection in each of the others (fig. 7B).

Distribution of coliform bacteria concentrations was highly influenced by many samples that tested negative; and, of the samples that tested positive, many concentrations were near the minimum reporting limit (fig. 8). More than 75 percent of total coliform and E. coli concentrations in samples from 9 of the 16 aquifers were $<1 \mathrm{CFU} / 100 \mathrm{~mL}$. Concentrations of total coliforms tended to be distributed somewhat higher in samples from four aquifers: 25 percent of the concentrations ranged from 1 to $7 \mathrm{CFU} / 100 \mathrm{~mL}$ in samples from the Floridan aquifer; from 1 to $4 \mathrm{CFU} / 100 \mathrm{~mL}$ in samples from the Piedmont and Blue Ridge aquifer; from $<1$ to $4 \mathrm{CFU} / 100 \mathrm{~mL}$ in samples from the North Atlantic Coastal Plain aquifer; and from $<1$ to $2 \mathrm{CFU} / 100 \mathrm{~mL}$ in samples from the Central Valley aquifer. 

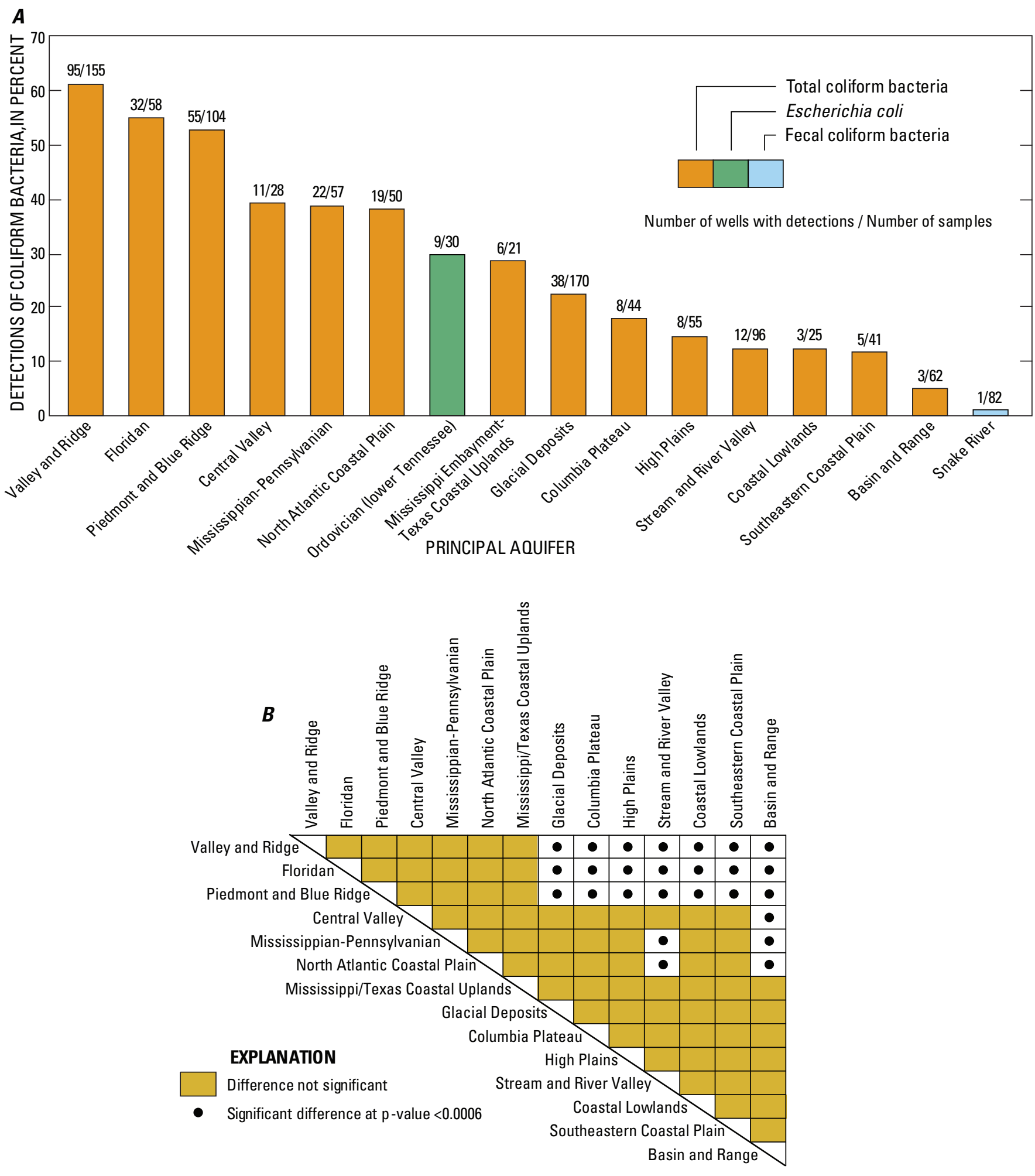

Figure 6. Percentage of wells testing positive for coliform bacteria $(A)$, and significantly different ( $p$-value $<0.0006$ ) detection frequencies of total coliform bacteria $(B)$ by principal aquifer from data collected in 22 study units of the National Water-Quality Assessment program, 1993-2004. 
Table 5. Summary of microbiological data collected from wells in each principal aquifer in 22 study units of the National Water-Quality Assessment Program, 1993-2004.

[Abbreviations: CFU/100mL, colony-forming units per 100 milliliters. Symbols: <, less than; >, greater than; -, no data or not applicable]

\begin{tabular}{|c|c|c|c|c|c|c|c|}
\hline \multirow{3}{*}{$\begin{array}{c}\text { Tests } \\
\text { Total coliform }\end{array}$} & \multirow{3}{*}{$\begin{array}{l}\text { Principal aquifer } \\
\text { Valley and Ridge }\end{array}$} & \multirow{3}{*}{$\begin{array}{c}\text { Number } \\
\text { of wells }\end{array}$} & \multirow{2}{*}{\multicolumn{2}{|c|}{$\begin{array}{l}\text { Number of wells } \\
\text { with detections } \\
\text { (percentage) }\end{array}$}} & \multicolumn{3}{|c|}{$\begin{array}{l}\text { Concentration } \\
\text { (CFU/100mL) }\end{array}$} \\
\hline & & & & & \multirow{2}{*}{$\frac{\text { Median }}{2}$} & \multicolumn{2}{|c|}{ Range } \\
\hline & & & 95 & $(61.3)$ & & $<1-$ & 1,600 \\
\hline & Mississippian-Pennsylvanian & 57 & 22 & $(38.6)$ & $<1$ & $<1-$ & 420 \\
\hline & Glacial Deposits & 170 & 38 & $(22.4)$ & $<1$ & $<1-$ & 110 \\
\hline & Floridan & 58 & 32 & $(55.2)$ & $<1$ & $<1-$ & $>80$ \\
\hline & Piedmont and Blue Ridge & 104 & 55 & $(52.9)$ & $<1$ & $<1-$ & $>80$ \\
\hline & North Atlantic Coastal Plain & 50 & 19 & $(38.0)$ & $<1$ & $<1-$ & $>80$ \\
\hline & Mississippi Embayment-Texas Coastal Uplands & 21 & 6 & $(28.6)$ & $<1$ & $<1-$ & 75 \\
\hline & Central Valley & 28 & 11 & $(39.3)$ & $<1$ & $<1-$ & 63 \\
\hline & Stream and River Valley & 96 & 12 & $(12.5)$ & $<1$ & $<1-$ & 60 \\
\hline & Southeastern Coastal Plain & 25 & 3 & $(12.0)$ & $<1$ & $<1-$ & 25 \\
\hline & Coastal Lowlands & 41 & 5 & $(12.2)$ & $<1$ & $<1-$ & 20 \\
\hline & Columbia Plateau & 44 & 8 & $(18.2)$ & $<1$ & $<1-$ & 18 \\
\hline & High Plains & 55 & 8 & $(14.5)$ & $<1$ & $<1-$ & 18 \\
\hline & Basin and Range & 62 & 3 & $(4.8)$ & $<1$ & $<1-$ & 5 \\
\hline & Ordovician (lower Tennessee) & 0 & \multicolumn{2}{|c|}{-} & - & \multicolumn{2}{|c|}{-} \\
\hline & Snake River & 0 & \multicolumn{2}{|c|}{-} & - & \multicolumn{2}{|c|}{-} \\
\hline \multirow[t]{16}{*}{ Escherichia coli } & Valley and Ridge & 113 & 39 & $(34.5)$ & $<1$ & $<1-$ & 1,200 \\
\hline & Ordovician (lower Tennessee) & 30 & 9 & $(30.0)$ & $<1$ & $<1-$ & 440 \\
\hline & Mississippian-Pennsylvanian & 121 & 18 & $(14.9)$ & $<1$ & $<1-$ & 340 \\
\hline & Snake River & 82 & 1 & $(1.2)$ & $<1$ & $<1-$ & 90 \\
\hline & Piedmont and Blue Ridge & 63 & 4 & $(6.3)$ & $<1$ & $<1-$ & 38 \\
\hline & Southeastern Coastal Plain & 35 & 2 & $(5.7)$ & $<1$ & $<1-$ & 23 \\
\hline & High Plains & 55 & 2 & $(3.6)$ & $<1$ & $<1-$ & 18 \\
\hline & Mississippi Embayment-Texas Coastal Uplands & 21 & 3 & $(14.3)$ & $<1$ & $<1-$ & 15 \\
\hline & Central Valley & 19 & 1 & $(5.3)$ & $<1$ & $<1-$ & 13 \\
\hline & North Atlantic Coastal Plain & 50 & 6 & $(12.0)$ & $<1$ & $<1-$ & 8 \\
\hline & Coastal Lowlands & 41 & 4 & $(9.8)$ & $<1$ & $<1-$ & 8 \\
\hline & Glacial Deposits & 146 & 8 & $(5.5)$ & $<1$ & $<1-$ & 8 \\
\hline & Floridan & 60 & 5 & $(8.3)$ & $<1$ & $<1-$ & 1 \\
\hline & Basin and Range & 62 & 1 & $(1.6)$ & $<1$ & $<1-$ & 1 \\
\hline & Stream and River Valley & 36 & 0 & $(0)$ & $<1$ & - & \\
\hline & Columbia Plateau & 44 & 0 & $(0)$ & $<1$ & - & \\
\hline
\end{tabular}




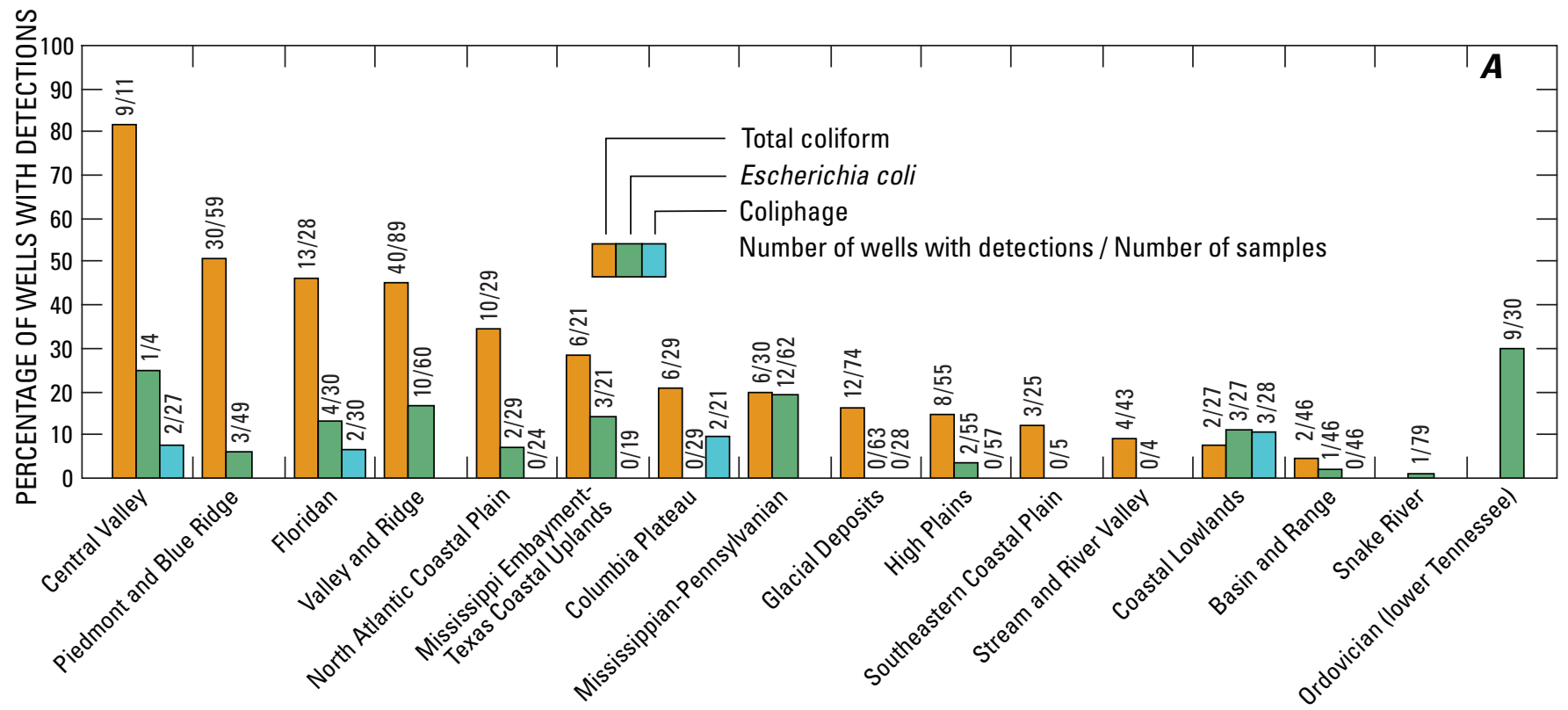

PRINCIPAL AQUIFERS OF THE MAJOR AQUIFER STUDIES (MAS)

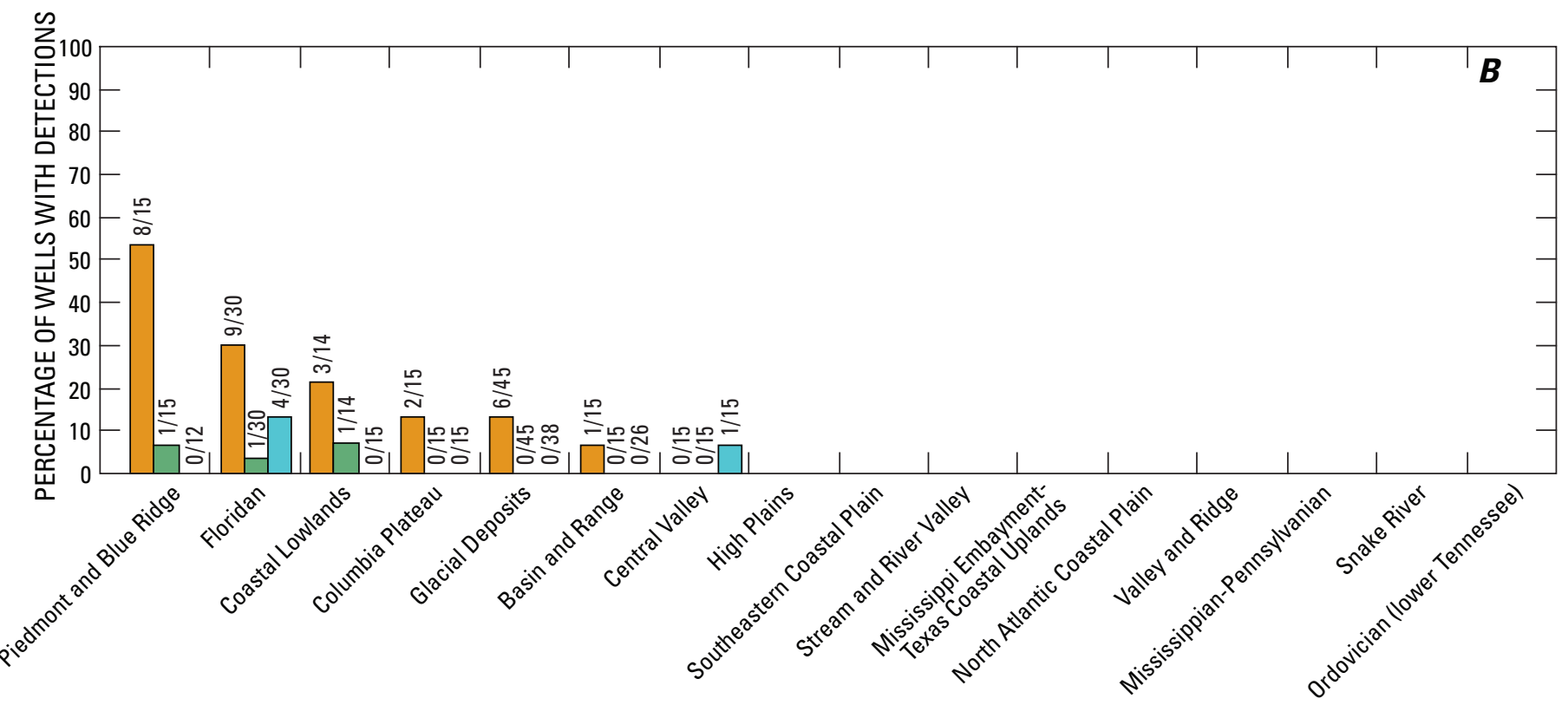

PRINCIPAL AQUIFERS OF THE SOURCE-WATER QUALITY ASSESSMENTS (SWQA)

Figure 7. Percentage of detections of coliform bacteria and coliphage virus in wells sampled as part of the major aquifer studies $(A)$ and source-water quality assessments $(B)$ for the National Water-Quality Assessment program, 1993-2004. 


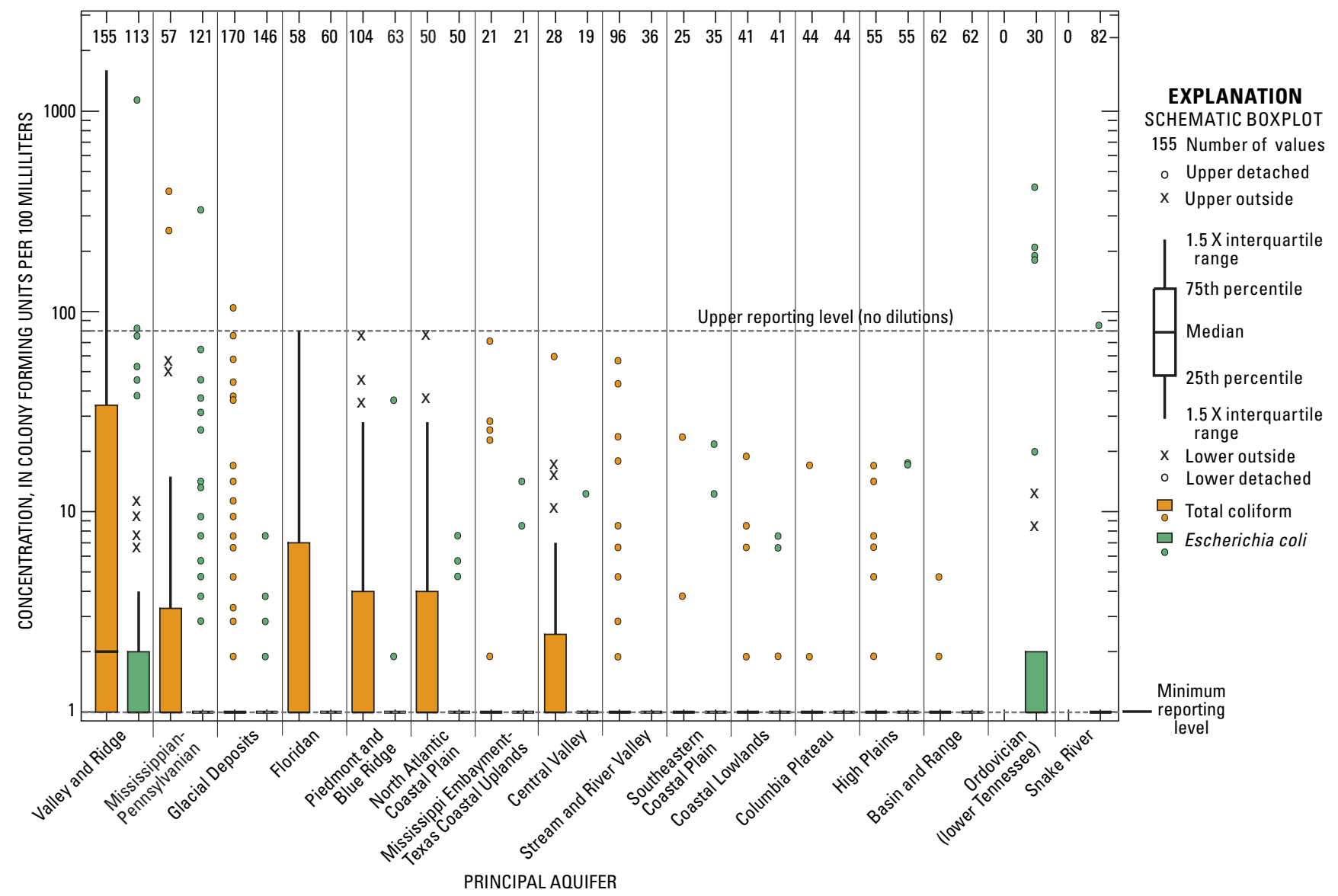

Figure 8. Concentrations of total coliform and Escherichia coli by principal aquifer in samples collected in 22 study units of the National Water-Quality Assessment program, 1993-2004.

Maximum concentrations of total coliforms of $1,600 \mathrm{CFU} / 100 \mathrm{~mL}$ and of $E$. coli of $1,200 \mathrm{CFU} / 100 \mathrm{~mL}$ were detected in a sample from a well completed in carbonate rocks (dolomite) of the Valley and Ridge aquifer. This aquifer also had the highest overall concentrations of total coliform bacteria, with a median of $2 \mathrm{CFU} / 100 \mathrm{~mL}$ (table 5) and 25 percent of the concentrations ranging from 2 to $34 \mathrm{CFU} / 100 \mathrm{~mL}$ (fig. 8). High concentrations of coliform bacteria (greater than $300 \mathrm{CFU} / 100 \mathrm{~mL}$ ) also were detected in samples from the Mississippian-Pennsylvanian and
Ordovician aquifers. For wells in the Floridan, Piedmont and Blue Ridge, and North Atlantic Coastal Plain aquifers, high concentrations were reported only to the upper limit of the analytical method (80 CFU/100mL) for an undiluted sample, so the maximum concentrations are unknown. For the MAS, however, the aquifers with the highest overall concentrations of total coliform bacteria were the Floridan, with a median of $4 \mathrm{CFU} / 100 \mathrm{~mL}$, and the Central Valley, with a median of $3 \mathrm{CFU} / 100 \mathrm{~mL}$. 


\section{Detection of Coliform Bacteria in Principal Aquifers of Different Lithologies}

Variations in the detection frequencies of coliform bacteria and in the distribution of their concentrations among principal aquifers are explained in part by types of lithology. Detection frequencies were greater for wells in carbonate rocks (primarily limestone and dolomite), crystalline rocks (primarily undifferentiated metamorphic rocks and schist) or sandstone, shale, undifferentiated sedimentary rocks, than for wells in unconsolidated materials (different mixtures of sand, gravel, and clay, or alluvium), semiconsolidated sand, or volcanic rocks (basalt, with sand and gravel interbeds) (fig. 9A). More than 50 percent of all sampled wells completed in carbonate rocks, such as those that make up part of the of the Valley and Ridge, the Floridan, and the Piedmont and Blue Ridge aquifers (table 2), or in crystalline rocks of the Piedmont and Blue Ridge aquifers tested positive for coliform bacteria (fig. 9A, table 6). The frequency of detection of coliform bacteria in wells completed in unconsolidated materials tends to be relatively low (less than about 20 percent), and is significantly lower ( $\mathrm{p}$-value $<0.002$ ) than detections for wells completed in consolidated rocks (fig. 9B). Principal aquifers composed primarily of these unconsolidated materials and with low detection frequencies include the Basin and Range, Coastal Lowlands, Southeastern Coastal Plain, Stream and River Valley, and High Plains.

Relatively high concentrations of fecal-indicator bacteria were detected in wells completed in carbonate rocks, with 25 percent of the total-coliform values ranging from 1 to $24 \mathrm{CFU} / 100 \mathrm{~mL}$ (fig. 10). Carbonate-rock aquifers with high concentrations of total coliforms or $E$. coli include the Floridan, the Ordovician in the lower Tennessee region, the Valley and Ridge, the Piedmont and Blue Ridge, and the Mississippian-Pennsylvanian. Concentrations of total coliforms in unconsolidated materials were generally low, with medians of $<1 \mathrm{CFU} / 100 \mathrm{~mL}$.
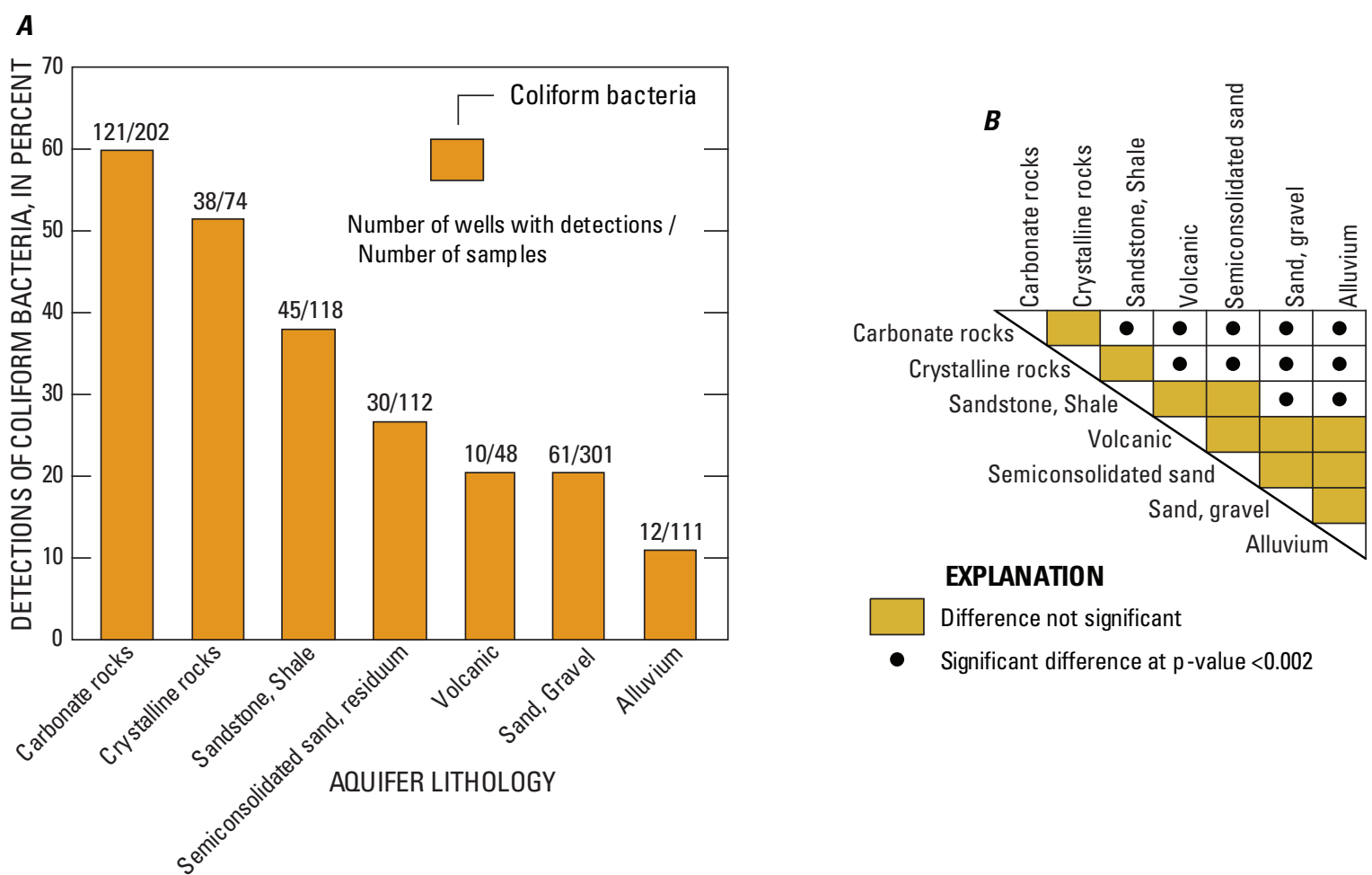

Figure 9. Percentage of wells testing positive for coliform bacteria $(A)$, and significantly different detection frequencies ( $p$-value $<0.002$ ) of total coliform bacteria with respect to aquifer lithology $(B)$. Graphs are based on data collected in 22 study units of the National Water-Quality Assessment program, 1993-2004. 
Table 6. Summary of microbiological data, by type of principal-aquifer lithology, collected from wells in 22 study units of the National Water-Quality Assessment program, 1993-2004.

[Type of lithology: residuum, remains from chemical and physical weathering of parent aquifer materials or formation. Abbreviations: CFU/100mL, colony-forming units per 100 milliliters; <, less than; >, greater than; -, no data or not applicable]

\begin{tabular}{|c|c|c|c|c|c|c|}
\hline \multirow[t]{2}{*}{ Tests } & \multirow[t]{2}{*}{ Type of lithology } & \multirow{2}{*}{$\begin{array}{l}\text { Number } \\
\text { of wells }\end{array}$} & \multirow{2}{*}{\multicolumn{2}{|c|}{$\begin{array}{c}\text { Number of wells } \\
\text { with detections } \\
\text { (percentage) }\end{array}$}} & \multicolumn{2}{|c|}{$\begin{array}{l}\text { Concentration } \\
\text { (CFU/100mL) }\end{array}$} \\
\hline & & & & & Median & Range \\
\hline \multirow[t]{7}{*}{ Total coliform } & Carbonate rocks (limestone, dolomite) & 202 & 121 & $(59.9)$ & 2 & $<1-1,600$ \\
\hline & Sandstone, shale & 118 & 45 & $(38.1)$ & $<1$ & $<1-420$ \\
\hline & Crystalline rocks & 74 & 38 & $(51.4)$ & 1 & $<1->80$ \\
\hline & Semiconsolidated sand, residuum & 112 & 30 & $(26.8)$ & $<1$ & $<1->80$ \\
\hline & Volcanic & 48 & 10 & $(20.8)$ & $<1$ & $<1->18$ \\
\hline & Sand, gravel & 301 & 61 & $(20.3)$ & $<1$ & $<1->110$ \\
\hline & Alluvium & 111 & 12 & $(10.8)$ & $<1$ & $<1-\quad 60$ \\
\hline \multirow[t]{7}{*}{ Escherichia coli } & Carbonate rocks (limestone, dolomite) & 253 & 65 & $(25.7)$ & $<1$ & $<1-1,200$ \\
\hline & Volcanic & 130 & 2 & $(1.5)$ & $<1$ & $<1-\quad 90$ \\
\hline & Crystalline rocks & 63 & 4 & $(6.3)$ & $<1$ & $<1-\quad 38$ \\
\hline & Sand, gravel & 280 & 13 & $(4.6)$ & $<1$ & $<1-\quad 23$ \\
\hline & Semiconsolidated sand, residuum & 112 & 13 & $(11.6)$ & $<1$ & $<1-\quad 15$ \\
\hline & Sandstone, shale & 89 & 7 & $(7.9)$ & $<1$ & $<1-\quad 33$ \\
\hline & Alluvium & 51 & 0 & (0) & $<1$ & - \\
\hline \multirow[t]{7}{*}{ Coliphage } & Semiconsolidated sand, residuum & 86 & 3 & $(3.5)$ & - & - \\
\hline & Volcanic & 40 & 2 & $(5.0)$ & - & - \\
\hline & Carbonate rocks (limestone, dolomite) & 78 & 6 & $(7.7)$ & - & - \\
\hline & Sand, gravel & 192 & 2 & $(1.0)$ & - & - \\
\hline & Crystalline rocks & 12 & 0 & $(0)$ & - & - \\
\hline & Sandstone, shale & 0 & - & - & - & - \\
\hline & Alluvium & 15 & 1 & $(6.7)$ & - & - \\
\hline
\end{tabular}

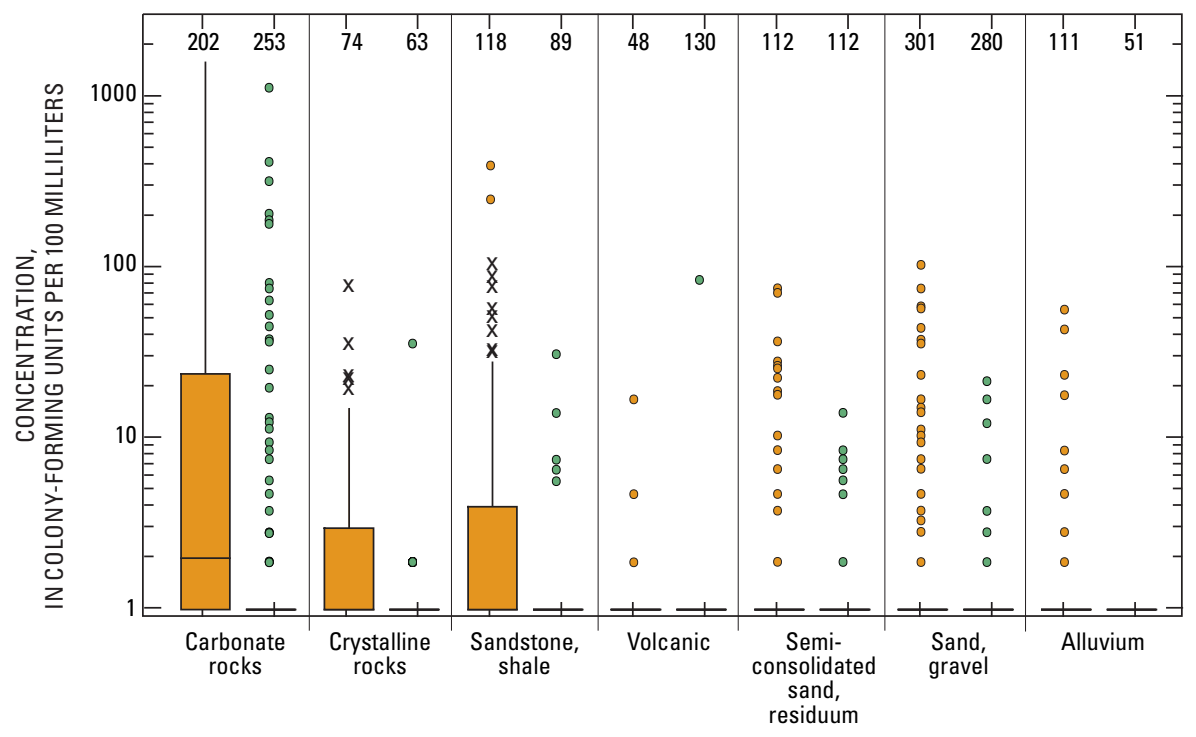

EXPLANATION SCHEMATIC BOXPLOT 202 Number of values

- Upper detached

$x$ Upper outside

$1.5 \mathrm{X}$ interquartile range

75 th percentile

Median

25th percentile

$1.5 \mathrm{X}$ interquartile range

$x$ Lower outside

- Lower detached

$\square$ Total coliform

ㅁ Escherichia coli

Figure 10. Concentrations of total coliform and Escherichia coli by principal aquifer lithology in samples collected in 22 study units of the National Water-Quality Assessment program, 1993-2004. 
Water Use, Drinking-Water Supplies, and Wells of the Major Aquifer Study and Source-Water Quality Assessment Networks

The MAS and SWQA study networks focused on the quality of ground water used for drinking-water supplies through the sampling of about 630 wells used for domestic and public supplies. Total coliforms were detected in 27 percent and $E$. coli in 6 percent of these wells. Most (71 percent) of the MAS wells were domestic wells; however, an additional 15 percent of MAS wells were used for public supplies (fig. 11). Conversely, and by study design, nearly all of the SWQA wells were used for public supplies. A few SWQA wells, however, were described as unused at the time of sampling and one was described as a domestic well (fig. 11).

Of the 6 classes of water use considered in this analysis, wells used for domestic purposes made up the largest class, with data on total-coliform concentrations available for 405 wells and on E. coli concentrations for 397 wells. The domestic-use class was followed by public supply and unused classes with total-coliform concentrations for 227 and 37 wells, respectively (table 7). Total coliforms were detected in
33 percent of the samples from domestic wells and 16 percent of samples from public supply wells, and $E$. coli were detected in 8 and 3 percent of samples from domestic and public supply wells, respectively (fig. 12A).

Median concentrations of total coliforms and E. coli were at the detection limit of $<1 \mathrm{CFU} / 100 \mathrm{~mL}$ for all 6 classes of water use (fig. $12 \mathrm{~B}$, table 7 ); however, the concentrations in domestic wells were significantly higher ( $\mathrm{p}$-value $<0.05$ ) than concentrations in public-supply wells. In samples from domestic wells, the maximum concentrations of total coliforms and E. coli were 1,600 and 1,200 CFU/100mL, respectively. Maximum concentrations of total coliforms detected in samples from public-supply wells were $>80$ CFU/100mL for a well completed in the Floridan aquifer of the GAFL study unit, and $61 \mathrm{CFU} / 100 \mathrm{~mL}$ for a well completed in the Glacial Deposits aquifer of the HPGW study unit. More than 75 percent of samples from domestic wells had concentrations of total coliforms of $2 \mathrm{CFU} / 100 \mathrm{~mL}$ or less. In samples from public-supply wells, however, more than 75 percent of concentrations of total coliforms were less than

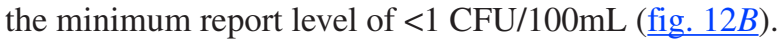

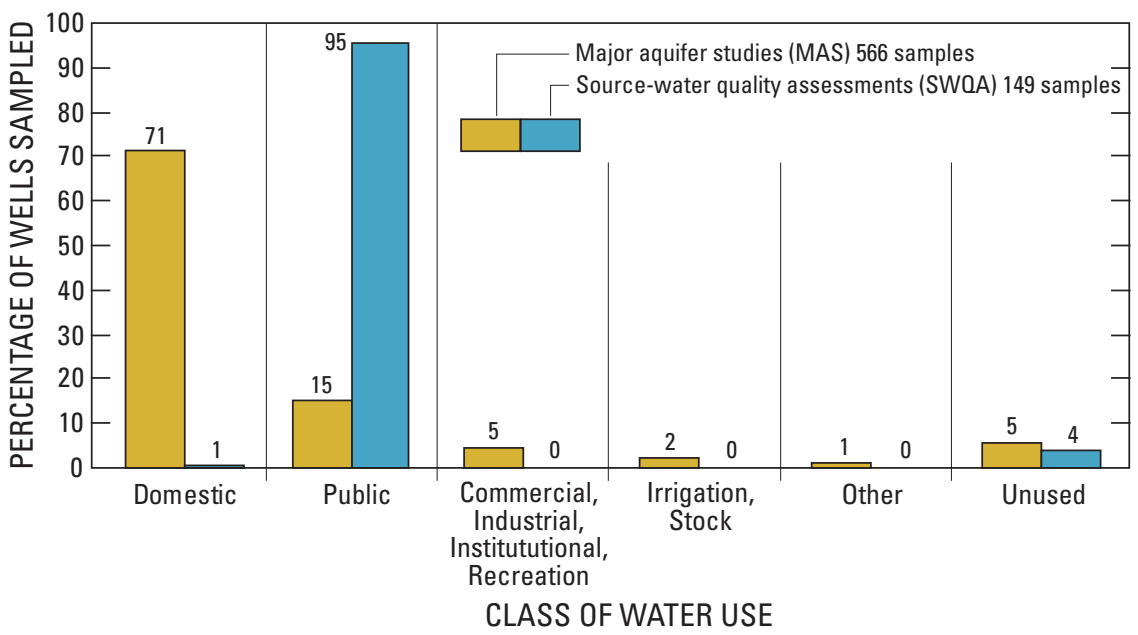

Figure 11. Percentage of major aquifer study (MAS) and source-water quality assessment (SWOA) wells sampled by class of water use in 22 study units of the National Water-Quality Assessment program, 1993-2004. 
Table 7. Summary of microbiological data collected from major aquifer study and source-water-quality assessment wells used for domestic, public supply, and other purposes, and from unused wells by the National Water-Quality Assessment Program, 1993-2004.

[Abbreviations: CFU/100mL, colony-forming units per 100 milliliters; coliphage reported as present or absent only. Symbols: <, less than; >, greater than; -, no data or not applicable]

\begin{tabular}{|c|c|c|c|c|c|}
\hline \multirow[t]{2}{*}{ Tests } & \multirow[t]{2}{*}{ Water use } & \multirow{2}{*}{$\begin{array}{l}\text { Number of } \\
\text { wells }\end{array}$} & \multirow{2}{*}{$\begin{array}{c}\text { Number of } \\
\text { detections } \\
\text { (percentage) }\end{array}$} & \multicolumn{2}{|c|}{$\begin{array}{l}\text { Concentration } \\
\text { (CFU/100mL) }\end{array}$} \\
\hline & & & & Median & Range \\
\hline \multirow[t]{6}{*}{ Total coliform } & Domestic & 405 & 134 (33.1) & $<1$ & $<1-1,600$ \\
\hline & Public & 227 & $36 \quad(15.9)$ & $<1$ & $<1->80$ \\
\hline & $\begin{array}{l}\text { Commercial, industrial, } \\
\text { institution, recreation }\end{array}$ & 27 & $9 \quad(33.3)$ & $<1$ & $<1->80$ \\
\hline & Irrigation, stock & 12 & $3(25.0)$ & $<1$ & $<1-\quad 25$ \\
\hline & Other & 7 & $1 \quad(14.3)$ & $<1$ & $<1-\quad 1$ \\
\hline & Unused & 37 & $8 \quad(21.6)$ & $<1$ & $<1-178$ \\
\hline \multirow[t]{6}{*}{ Escherichia coli } & Domestic & 397 & 31 (7.8) & $<1$ & $<1-1,200$ \\
\hline & Public & 220 & $6 \quad(2.7)$ & $<1$ & $<1-\quad 14$ \\
\hline & $\begin{array}{l}\text { Commercial, industrial, } \\
\text { institution, recreation }\end{array}$ & 24 & 1 (4.2) & $<1$ & $<1-\quad 6$ \\
\hline & Irrigation, stock & 38 & $3 \quad(7.9)$ & $<1$ & $<1-440$ \\
\hline & Other & 14 & $4 \quad(28.6)$ & $<1$ & $<1-\quad 14$ \\
\hline & Unused & 48 & $9 \quad(18.8)$ & $<1$ & $<1-\quad 68$ \\
\hline \multirow[t]{6}{*}{ Coliphage } & Domestic & 200 & $7 \quad(3.5)$ & - & - \\
\hline & Public & 183 & $5 \quad(2.7)$ & - & - \\
\hline & $\begin{array}{l}\text { Commercial, industrial, } \\
\text { institution, recreation }\end{array}$ & 6 & $1 \quad(16.7)$ & - & - \\
\hline & Irrigation, stock & 2 & $0 \quad(0)$ & - & - \\
\hline & Other & 4 & $0 \quad(0)$ & - & - \\
\hline & Unused & 25 & $1 \quad(4.0)$ & - & - \\
\hline
\end{tabular}


$\boldsymbol{A}$
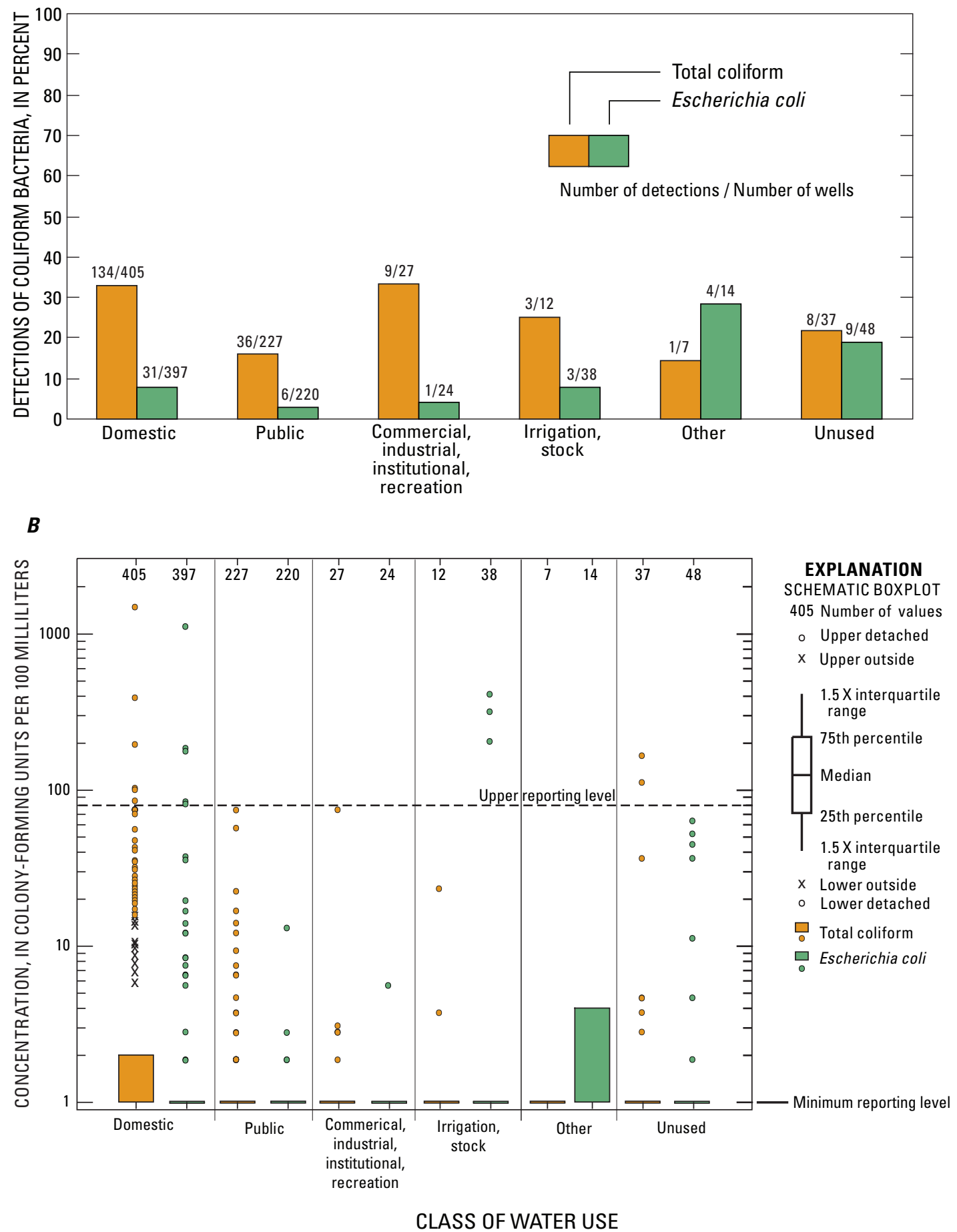

Figure 12. Percentage of wells testing positive for coliform bacteria $(A)$, and concentrations of coliform bacteria by class of water use $(B)$ in samples collected in major aquifer study (MAS) and source-water quality assessment (SWQA) wells in 22 study units of the National Water-Quality Assessment program, 1993-2004. 


\section{Coliphage Viruses and Water Supplies}

Samples for wells completed in 10 principal aquifers were analyzed for the presence of coliphage (table 8). Wells in 9 of these 10 aquifers were sampled as part of the MAS networks and wells in 7 of the aquifers were sampled as part of the SWQA networks. In 4 aquifers (Floridan, Central Valley, Coastal Lowlands, and Columbia Plateau), from 2 to 6 wells tested positive for coliphage (fig. 7A and $\underline{B})$. Although no coliphages were detected in public-supply wells sampled in the Coastal Lowlands aquifer, coliphages were detected in 3 of 24 public-supply wells in the Floridan aquifer, in 1 of 15 public-supply wells in the Central Valley aquifer, and in 1 of 34 public-supply wells in the Columbia Plateau aquifer. A few domestic wells also tested positive for coliphage, but the frequency of detection was less than

Table 8. Summary of coliphage data collected from major aquifer study and source-water quality assessment wells in each principal aquifer studied by the National Water-Quality Assessment program, 1993-2004.

[Abbreviations: -, no data or not applicable]

\begin{tabular}{|c|c|c|}
\hline Principal aquifer & $\begin{array}{l}\text { Number } \\
\text { of wells }\end{array}$ & $\begin{array}{c}\text { Number of wells } \\
\text { with detections } \\
\text { (percentage) }\end{array}$ \\
\hline Floridan & 60 & $6(10.0)$ \\
\hline Central Valley & 42 & $3(7.1)$ \\
\hline Coastal Lowlands & 43 & $3(7.0)$ \\
\hline Columbia Plateau & 36 & $2 \quad(5.6)$ \\
\hline Piedmont and Blue Ridge & 12 & $0 \quad(0)$ \\
\hline Basin and Range & 61 & $0 \quad(0)$ \\
\hline Glacial Deposits & 66 & $0 \quad(0)$ \\
\hline High Plains & 57 & $0 \quad(0)$ \\
\hline $\begin{array}{l}\text { Mississippi Embayment-Texas Coastal } \\
\text { Uplands }\end{array}$ & 19 & $0 \quad(0)$ \\
\hline North Atlantic Coastal Plain & 24 & $0 \quad(0)$ \\
\hline Ordovician (lower Tennessee) & 0 & - \\
\hline Valley and Ridge & 0 & - \\
\hline Mississippian-Pennsylvanian & 0 & - \\
\hline Southeastern Coastal Plain & 0 & - \\
\hline Stream and River Valley Alluvial & 0 & - \\
\hline Snake River & 0 & - \\
\hline
\end{tabular}

4 percent. Only 7 of all 200 domestic wells and 5 of all 183 (less than 3 percent) public-supply wells sampled tested positive for coliphage (table 7).

The presence or absence of coliphage viruses in samples did not show any relation to concentrations of total coliforms or E. coli. Specifically, coliphage could be present with total coliforms at low concentrations of $1 \mathrm{CFU} / 100 \mathrm{~mL}$ or less (undetected), or they could be absent from samples when total-coliform concentrations were as high as $100 \mathrm{CFU} / 100 \mathrm{~mL}$ (fig. 13). Only one of the coliphage-positive samples also tested positive for E. coli. This lack of co-occurrence of bacteria and coliphage is consistent with the understanding that no single organism can fully function as an indicator for the presence of different types of microorganisms (Cabelli, 1978; Havelaar and others, 1993). In a study of small publicsupply systems, Francy and others (2004) also determined a lack of co-occurrence between concentrations or detections of coliform bacteria and coliphage.

\section{Occurrence of Coliform Bacteria and Relation to Well Depth and Selected Water-Quality Characteristics}

The Kruskal-Wallis test indicated that one or more groups of well depths within study networks, uses of water, principal aquifers, and lithology differed (p-values $<0.05$ ) in their medians or distribution of values. Wells in the SWQA and MAS networks with median depths of 400 feet and 150 feet below land surface, respectively, were significantly deeper than wells of the LUS networks (median depth of about 50 feet below land surface), and public-supply wells (median depth of 427 feet) were deeper than wells used for domestic supply (median depth of 161 feet) or other purposes (fig. 14). For all 16 principal aquifers, the deepest wells sampled, with a median depth of 400 feet below land surface, were those in the Basin and Range aquifer (fig. 15). The depths of the publicsupply wells in the SWQA network and the wells in the Basin and Range aquifer might explain, in part, the relatively low detection frequencies of the coliform bacteria in these wells. A thick unsaturated zone increases the potential for natural attenuation of microorganisms, thereby reducing the potential for or preventing the bacteria being transported into the ground water. 
All samples from wells in the Major Aquifer Studies

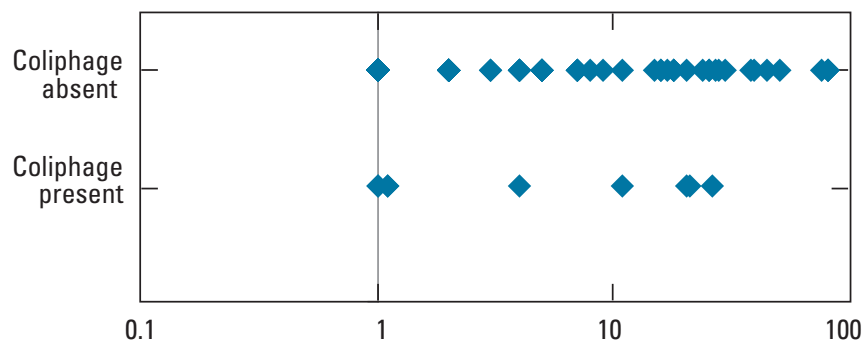

Columbia Plateau Aquifer, Volcanic rocks

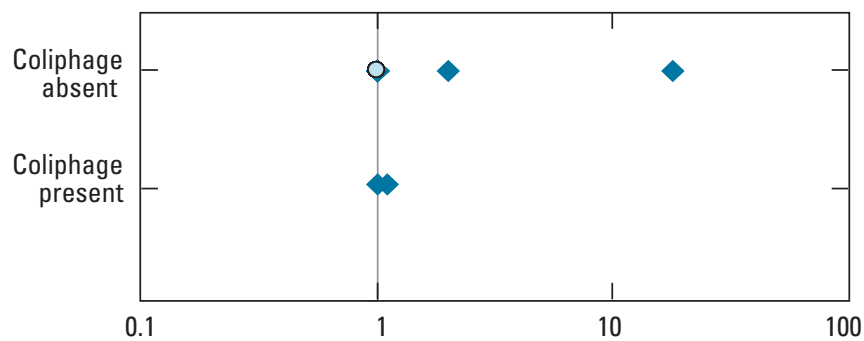

Central Valley Aquifer,

Sand, Grave

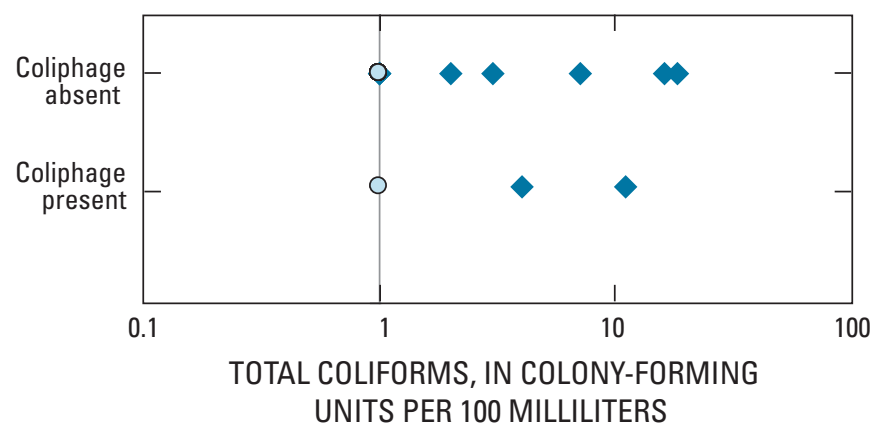

All samples from wells in the SourceWater Quality Assessment

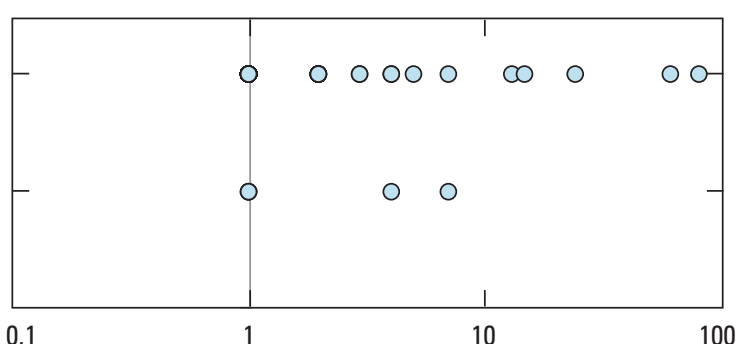

Floridan Aquifer, Carbonate rocks

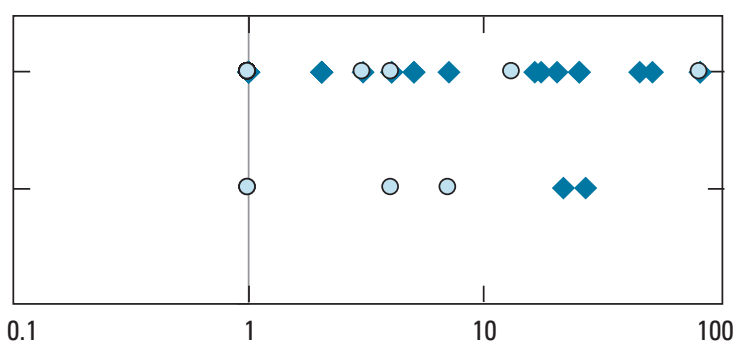

Coastal Lowlands Aquifer, Sand, Gravel

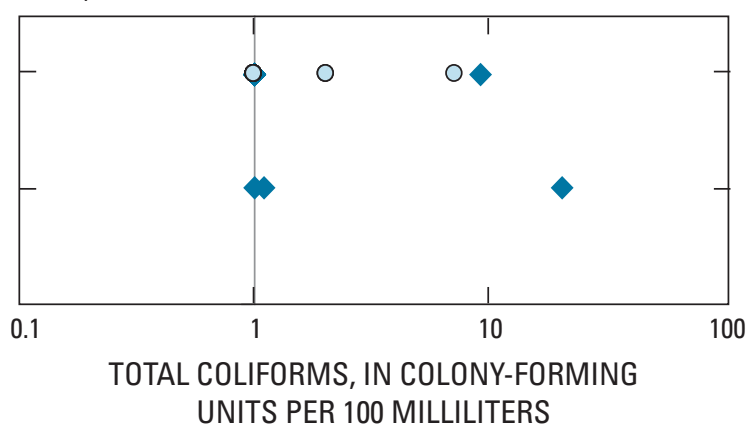

EXPLANATION

- Sample from well in the Major Aquifer Study (MAS) Network

- Sample from well in the Source-Water Quality Assessment (SWQA) Network

Figure 13. Relation of the presence or absence of coliphage virus to concentrations of total coliforms for wells in the major aquifer study (MAS) networks and source-water quality assessment (SWQA) networks, and for principal aquifers with coliphage-positive wells. 

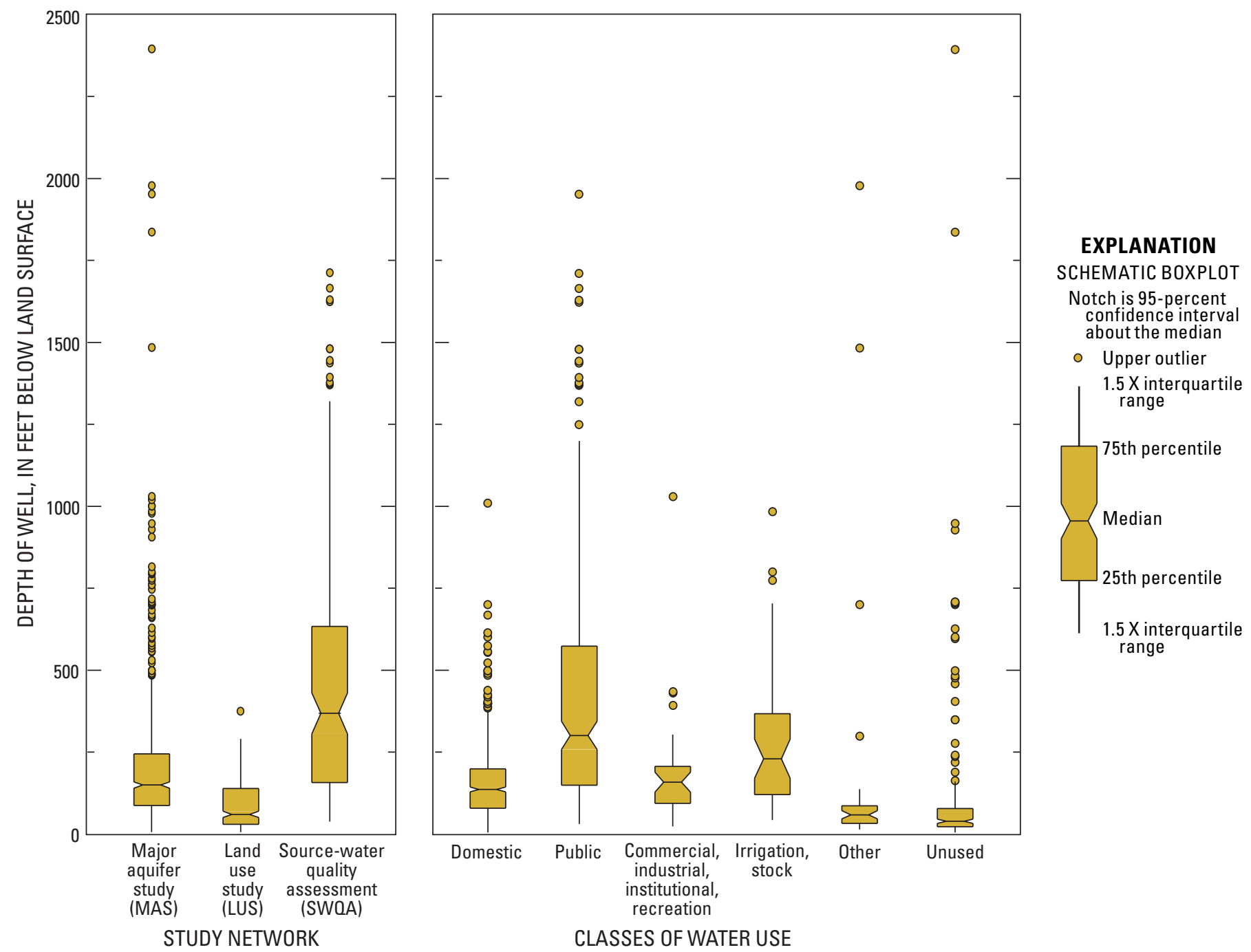

Figure 14. Distributions of well depths for the major aquifer study (MAS), land use study (LUS), and source-water quality assessment (SWQA) networks, and distribution of well depths for the classes of water use, from data collected in 22 study units of the National Water-Quality Assessment program, 1993-2004. 


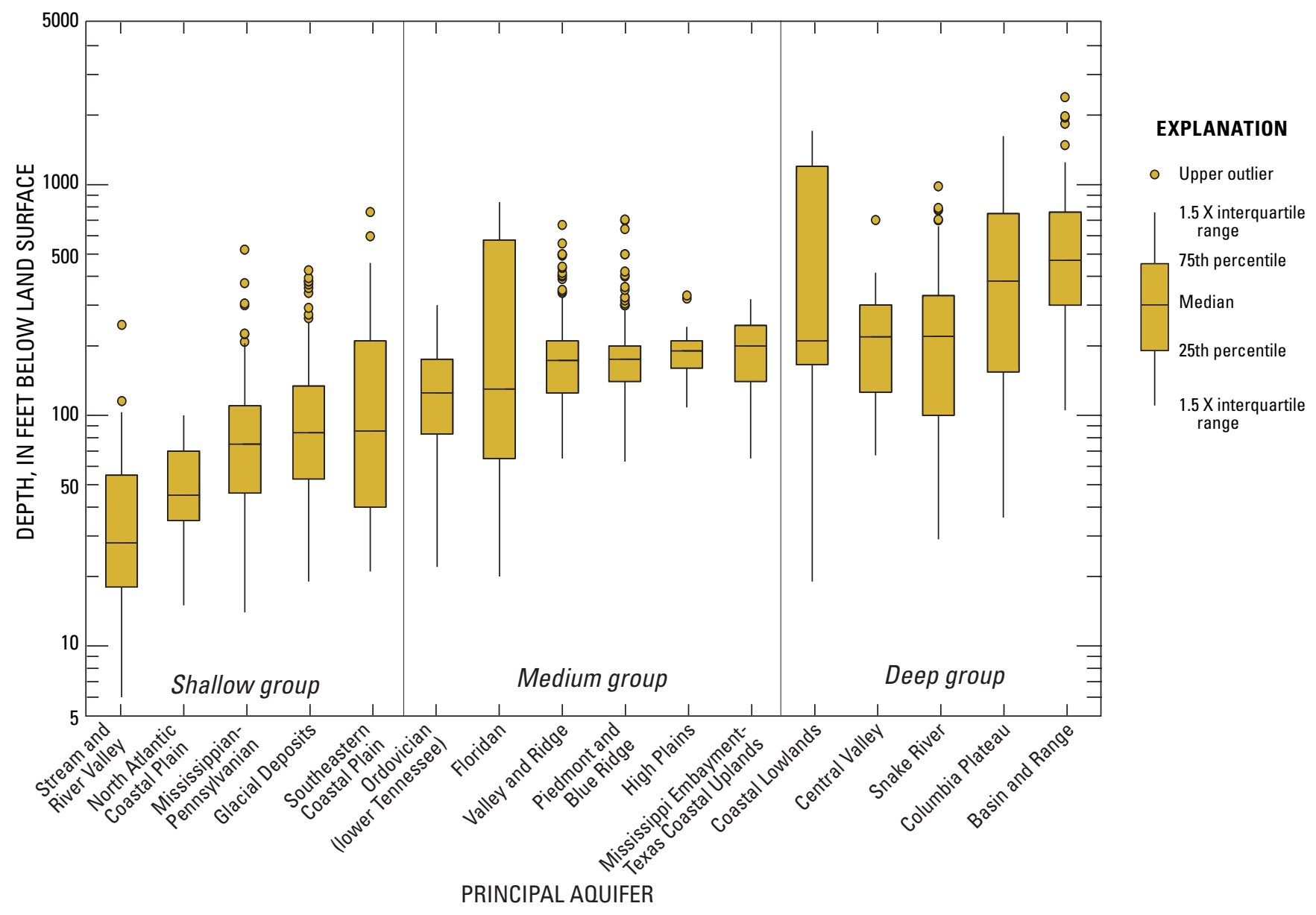

Figure 15. Distribution of well depths in the 16 principal aquifers studied by the National Water-Quality Assessment program, 1993-2004.

The principal aquifers were combined on the basis of median depths of sampled wells into three groups-shallow (median depths $<100$ feet), medium (median depths from 100 to 200 feet), and deep (median depths greater than 200 feet) to identify any relations between well depth and detection frequencies or concentrations of total coliform bacteria (fig. 16). Of a total of 317 detections of total coliform bacteria, 91 percent of the detections occurred in principal aquifers with median depths of sampled wells 200 feet deep or less, whereas only 9 percent of the detections occurred in the group of principal aquifers with median depths of sampled wells greater than 200 feet. The highest frequency of detection (50 percent) was in samples from wells in the medium group of aquifers with median well depths ranging from 100 to 200 feet (fig. 16).
For wells in which total coliform bacteria were detected, concentrations in wells in the deep group of principal aquifers were lower ( $\mathrm{p}$-value $<0.05$ ) than concentrations in wells in the shallow and medium groups of aquifers. The graphs of the data (fig. 16) also illustrate the poor relation between total coliform bacteria concentration and well depth, which indicates that other factors are likely controlling the occurrence and transport of coliform bacteria in the aquifers. Some of these other factors might be the geohydrologic characteristics of the aquifers (fractured and porous rock types), proximity of contaminating sources such as septic tanks (Francy and others, 2000), or age of the well (Bickford and others, 1996), along with other well-construction features. 

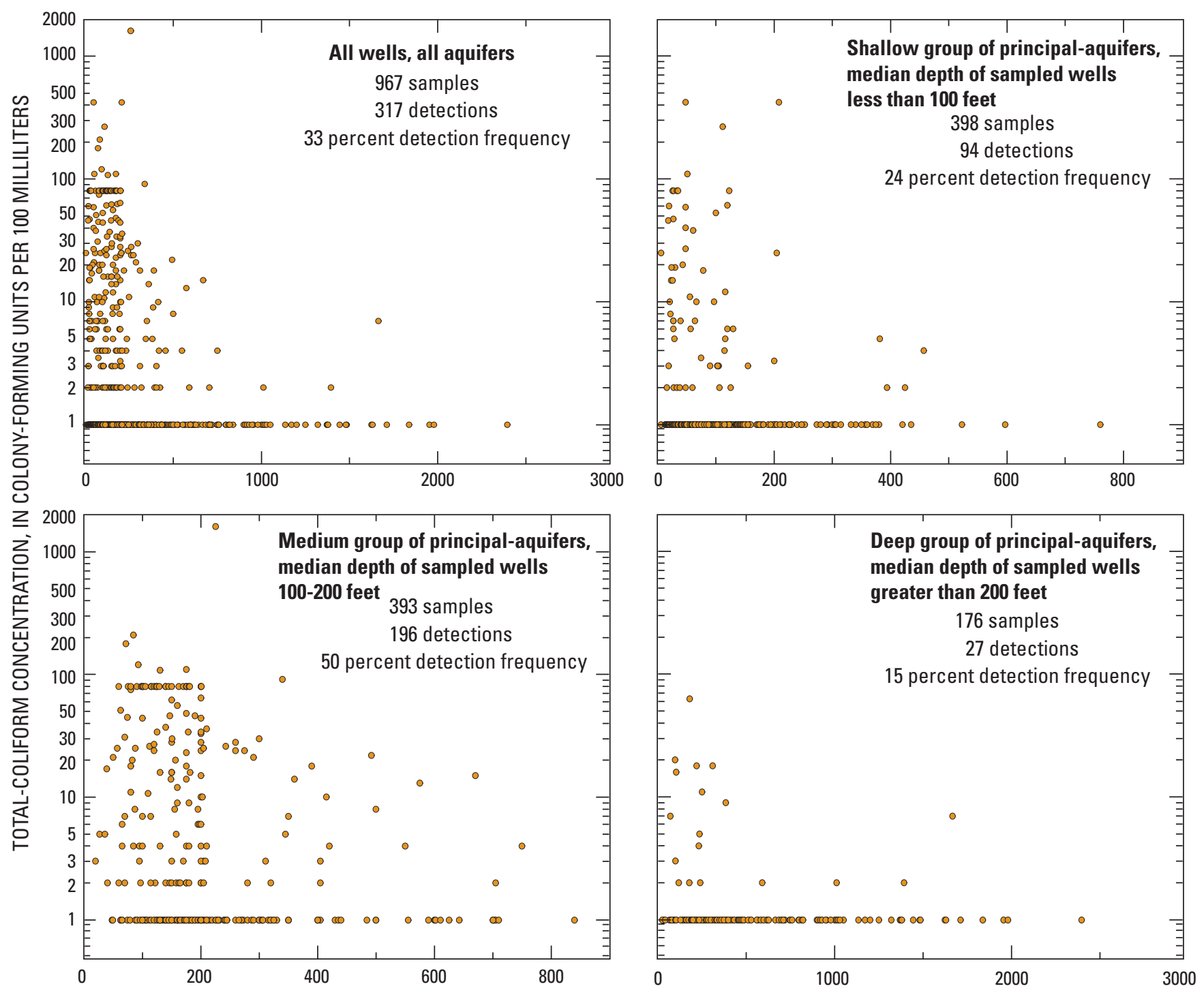

DEPTH OF WELL, IN FEET BELOW LAND SURFACE

Figure 16. Total-coliform concentrations and depths of wells for all 16 principal aquifers combined on the basis of the median depths of sampled wells, from data collected in 22 study units of the National Water-Quality Assessment program, 1993-2004.

The concentrations of selected chemical constituents (nutrients, major ions, dissolved oxygen, iron, manganese) and the measures of physical properties (specific conductance, water temperature) for samples collected from wells in the three major study networks also were evaluated for any relations to detections of total-coliform bacteria. There were significant differences (at the 95-percent confidence level) between median numbers of detections and nondetections of total coliforms with concentrations of dissolved oxygen, nitrite-plus-nitrate nitrogen, and orthophosphate (fig. 17). However, as with well depths, no strong correlation could be identified between the detection or nondetection of total-coliform bacteria in a water sample and the values of water-quality constituents. 

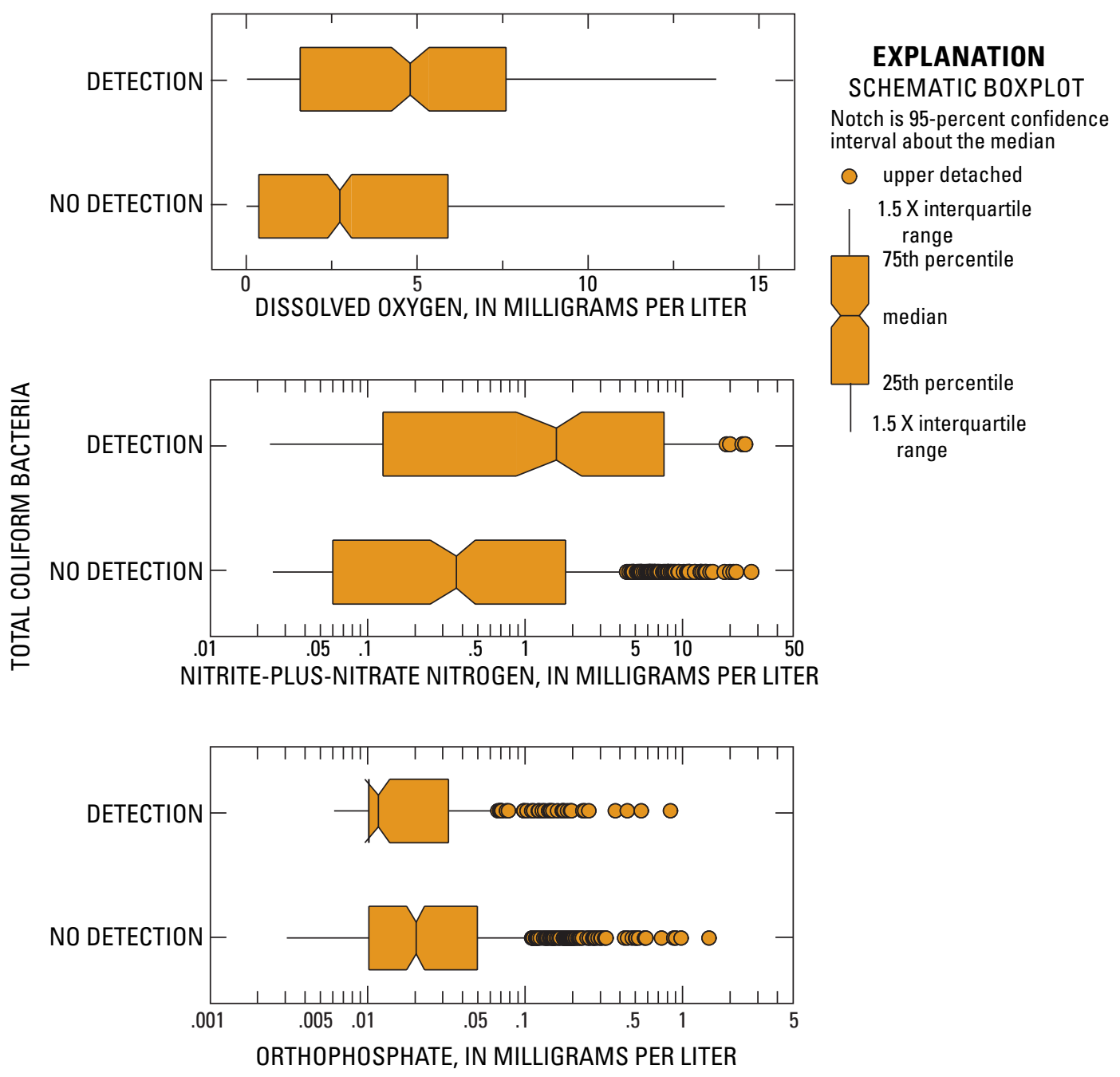

Figure 17. Detections of total-coliform bacteria with concentrations of dissolved oxygen, nitrite-plusnitrate nitrogen, and orthophosphate in samples collected from wells in 22 study units of the National Water-Quality Assessment program, 1993-2004.

\section{Discussion}

Three objectives governed this analysis of the microbiological quality of the Nation's ground water. First, to describe the spatial distribution and occurrence of selected fecal-indicator microorganisms in ground water on the basis of data collected for the NAWQA program from 1993 to early 2004. In addition, to determine how well the 19 principal aquifers that are the focus of the NAWQA Cycle II program are represented by the data and determine whether gaps are in the data on a regional basis. Second, to describe how fecal-indicator bacteria and coliphage are distributed within the aquifers by evaluating how microbial concentrations or detection frequencies relate to well depths, to types of aquifer materials, or to selected water-quality constituents or properties. Third, to identify what types and at what frequencies the fecal-indicator bacteria and coliphage are detected in water of the principal aquifers or in water used for drinking-water supplies. 
The set of microbiological data collected for the NAWQA program provided a relatively large number of observations with which to describe, in a general way, the geographic distribution and occurrence of fecal-indicator bacteria and coliphage in ground-water resources across the Nation. The data showed that wells testing positive for coliform bacteria exist within each study unit in which microbiological data were collected, with the highest frequencies of detections in wells in the northeastern and southeastern regions of the country and the fewest in the Idaho Upper Snake River and Nevada Basin and Range study areas. However, at the time of this analysis, fecal-indicator bacteria data had been collected in only 22 of the 50 NAWQA study units, and these data represented 12 of the 19 principal aquifers targeted by NAWQA in Cycle II. Additionally, data on the presence or absence of the coliphage viruses were collected in 11 of the 22 study units. Gaps in the data, therefore, included more than 20 study units and 7 principal aquifers for which fecalindicator bacteria data were unavailable and more than 30 study units for which coliphage data were unavailable for this analysis.

The Glacial Deposits, the Valley and Ridge, and the Piedmont and Blue Ridge aquifers had the greatest representation in the data, with a total of more than 420 analytical results for the fecal-indicator bacteria; no data, however, were available for the New England, EdwardsTrinity, California Coastal Basins, Biscayne, and CambrianOrdovician aquifers, or the Surficial aquifer systems of the Southeast. Aquifers that might be geographically underrepresented by this data set include the High Plains, except for the northernmost part; that part of the Basin and Range aquifer in Arizona and southern California; and the Denver Basin. Also geographically underrepresented are the Midwest regions and the greater Mississippi River Basin.

Another type of geographic underrepresentation would apply to the Glacial Deposits, North Atlantic Coastal Plain, Piedmont and Blue Ridge, and Coastal Lowlands principal aquifers. Although the data set contains relatively large numbers of results for these aquifers, the sampled wells are clustered in small, isolated areas and leave extensive areas of the aquifer without representation. The clustering is likely due to geographic boundaries of study units and to the types of well networks established for the NAWQA program, which dictated certain locations with suitable wells for meeting network study objectives.

Eleven of the 42 study units scheduled for inclusion in Cycle II are represented in this analysis. The advantages of microbiological data collected as part of Cycle II is a data set consisting of common analytical methods, target organisms, and quality assurance-quality control procedures. Forthcoming Cycle II data will help to fill some of the spatial gaps and greatly enhance the information on the occurrence of the coliphage viruses, for which testing only recently became part of regularly scheduled analyses for the well networks.
These additional data should prove valuable for a more comprehensive understanding of the quality of source waters for drinking-water supplies than described in this report.

The data showed general tendencies for detection frequencies and concentrations of total coliform bacteria to be higher (1) in principal aquifers with median well depths less than 200 feet than in principal aquifers with median well depths greater than 200 feet; (2) in domestic wells than in public-supply wells; and (3) in wells completed in fractured rocks or porous carbonate rocks than in sand, gravel, semiconsolidated sand, and volcanic rocks. Evaluations of the additional water-quality data (analyses for major chemical constituents) also showed tendencies for higher rates of total coliform detections with increasing concentrations of nitrite-plus-nitrate nitrogen and dissolved oxygen. With no strong correlations, however, the presence or absence of coliform bacteria cannot be predicted on the basis of well depth, lithology, or water chemistry, a situation that has been historically documented (Pipes, 1978, p. 106) and shown more recently in NAWQA studies by Bickford and others (1996) and Francy and others (2000). The data collected for the NAWQA program during 1993-2004 also showed that coliform bacteria tend to occur relatively frequently in ground water, with nearly 30 percent of the wells testing positive for these bacteria. Even though some of the members of the total coliform group originate from nonfecal sources, they can still function as conservative indicators of the potential for other microorganisms to enter the ground water. Conversely, E. coli and coliphage viruses indicate contamination from fecal and sewage sources, which could be a more serious situation with respect to potential presence of pathogenic microorganisms and human health. Fortunately, E. coli and coliphage were detected in ground water at much lower frequencies (11 percent and 3 percent, respectively) than the total-coliform bacteria.

This analysis provided insight into the quality of the ground water used for drinking-water supplies by revealing the large numbers of domestic wells affected by the presence of coliform bacteria. Total-coliform bacteria were detected in samples from 33 percent of 405 domestic wells and 16 percent of 227 public supply wells. No USEPA criteria or standards govern the acceptability of private-well water, and no routine monitoring is required for domestic supplies as for public supplies (U.S. Environmental Protection Agency, 2005). A study of ground water in California determined that about one-fourth of the privately owned wells used for domestic supply in a two-county study area had some level of contamination by fecal-indicator bacteria (Bowman, 2005). In response to that determination, the California State Water Resources Control Board suggested that the detections of bacteria and other contaminants might warrant a program of testing by homeowners at a proposed frequency of every 5 years (Bowman, 2005). The USEPA, recognizing that about 15 percent of the population relies on private drinking-water 
supplies, provides Internet-based educational materials and also recommends that these households take precautions to protect and maintain their systems in addition to obtaining periodic testing by a certified laboratory (U.S. Environmental Protection Agency, 2005).

The data collected for the NAWQA program and the summary of the microbial quality of ground water in this report provide a basic understanding and current description of occurrence and relatively widespread distribution of coliform bacteria. The results presented here can serve as a starting point for continued assessments of the microbial quality of water in the principal aquifers of the United States as the NAWQA data set expands and perhaps also serve as a basis for water and public-health managers concerned with groundwater resources at the local level, particularly those used for domestic purposes.

\section{Summary}

Microbiological data were collected from 1,205 wells in 22 study units of the National Water-Quality Assessment (NAWQA) program during 1993 to 2004, a period spanning the first decade (Cycle I) and the early part of the second decade (Cycle II) of the program. The samples of untreated ground water were analyzed primarily for concentrations of total-coliform bacteria, fecal-coliform bacteria, and Escherichia coli (E. coli), and for the presence of coliphage viruses. Water temperature, $\mathrm{pH}$, specific conductance, and dissolved-oxygen concentrations were measured at the time of sampling for microorganisms, and water samples were collected for analysis of a broad suite of chemical constituents, including nutrients.

The wells sampled for this analysis were part of NAWQA's specific study networks: those for the major-aquifer studies (MAS) and land-use (LUS) studies, and the wells sampled for the source-water-quality assessments (SWQA) of ground water used for public supplies. The networks were situated within 16 principal aquifers.

For the purpose of this analysis, wells were assigned to one of seven types of principal-aquifer lithology (consolidated carbonate rocks; crystalline rocks; sandstone-shale rocks; semiconsolidated sand; unconsolidated sands, gravels, or alluvium; and volcanic rocks) on the basis of well completion information. Wells were also assigned to one of six classes of water use.

Nearly 30 percent of the 1,174 wells used in the study tested positive for coliform bacteria. With at least one well in each study unit or principal aquifer testing positive, fecalindicator bacteria were geographically widespread. Detection frequencies for bacteria in wells within individual study units ranged from 1 percent of sampled wells in the Upper Snake to 70 percent of wells in the Lower Susquehanna.
Concentrations of total coliforms ranged from less than $(<) 1$ to 1,600 colony-forming units per 100 milliliters $(\mathrm{CFU} / 100 \mathrm{~mL})$ and concentrations of $E$. coli ranged from $<1$ to 1,200 CFU/100mL. Median concentrations for both total coliforms and E. coli, however, were at the reporting limit of $<1 \mathrm{CFU} /$ $100 \mathrm{~mL}$. Sixty-seven percent of total-coliform and 85 percent of $E$. coli concentrations were $<100 \mathrm{CFU} / 100 \mathrm{~mL}$, indicating that overall, concentrations tend to be low.

In 11 of the 22 study units, samples were collected from 423 wells to test for the presence of coliphage viruses. Coliphage were present in samples from 4 of the 11 study units-the Central Columbia Plateau-Yakima, GeorgiaFlorida, San Joaquin, and Trinity, representing the Columbia Plateau, Floridan, Central Valley, and Coastal Lowlands aquifers, respectively.

Wells used for domestic supply made up the largest class of water use, with total-coliform concentrations for 405 wells and $E$. coli concentrations for 397 wells, followed by publicsupply wells and unused wells with 227 and 37 concentrations of total-coliform bacteria, respectively. Total coliforms were detected in untreated water from 33 percent of domestic wells and 16 percent of public-supply wells; E. coli were detected in 8 and 3 percent of domestic and public-supply wells, respectively. Although median concentrations were $<1 \mathrm{CFU} / 100 \mathrm{~mL}$ for all classes of water use as defined in this report, the overall distribution of total-coliform concentrations was significantly higher in domestic wells than in publicsupply wells. Coliphage were present in less than 4 percent of domestic and public wells used for drinking-water supply.

More than 50 percent of the wells sampled in the Valley and Ridge, the Floridan, and the Piedmont and Blue Ridge principal aquifers tested positive for coliform bacteria. Detection rates for the Floridan and the Piedmont and Blue Ridge aquifers were significantly higher than those for the Glacial Deposits, Stream and River Valley, Columbia Plateau, Basin and Range, High Plains, Southeastern Coastal Plain, and Coastal Lowlands aquifers. In 9 of the 16 aquifers, more than 75 percent of the concentrations of total coliform and E. coli in samples were $<1 \mathrm{CFU} / 100 \mathrm{~mL}$. The maximum concentrations of total coliform bacteria and of $E$. coli detected in all samples analyzed were from a domestic well completed in dolomite of the Valley and Ridge principal aquifer. The highest overall concentrations of total coliform bacteria were detected in this aquifer with a median of $2 \mathrm{CFU} / 100 \mathrm{~mL}$. High concentrations of coliform bacteria (greater than [>] $300 \mathrm{CFU} / 100 \mathrm{~mL}$ ) also were detected in samples from the MississippianPennsylvanian aquifer and the Ordovician aquifer in the lower Tennessee region.

Generally, coliform bacteria were detected more frequently and in higher concentrations in wells completed in sandstone or shale, and in sedimentary, carbonate, and crystalline rocks than for wells in unconsolidated materials, in semiconsolidated sand, or in volcanic rocks. More than 
50 percent of sampled wells completed in carbonate rocks (limestone, dolomite) or in crystalline rocks (schist, granite) tested positive for coliform bacteria. The Floridan, Piedmont and Blue Ridge, Ordovician, and Valley and Ridge aquifers, all of which had high detection rates or concentrations of coliform bacteria, are composed of these fractured and porous rocks. The lowest rates of detections (less than 5 percent) were for wells in the Basin and Range and Snake River aquifers. Materials in these aquifers are primarily unconsolidated sand, gravel, and clay, or basalt with interbeds of sand, gravel, or clay.

The depths of public-supply wells (median of 427 feet below land surface) and of the wells in the Basin and Range aquifer (median depth of 400 feet) might explain in part, the relatively low detection frequencies of the coliform bacteria observed in these samples. A thick unsaturated zone increases the potential for natural attenuation of microorganisms, preventing the bacteria being transported into the ground water. Fifty-percent of wells in principal aquifers with median depths of sampled wells ranging from 100 to 200 feet below land surface tested positive for total coliform bacteria, whereas only 9 percent of wells in principal aquifers with median depths of sampled wells greater than 200 feet tested positive. However, there were no strong correlations between well depth and coliform bacteria detections or concentrations that would predict the presence of coliform bacteria for any given well.

The data collected for the NAWQA program and the summary of the microbial quality of ground water in this report provide a current description of the occurrence and relatively widespread distribution of coliform bacteria in the Nation's ground-water resources. The results presented here will serve as a starting point for continued assessments of the microbial quality of water in the principal aquifers.

\section{Acknowledgments}

The authors would like to thank Donna Francy and Don Stoeckel, Ohio Water Science Center of the USGS, for their guidance and advice during the data analysis. The helpful comments and suggestions for the report provided by USGS colleagues is greatly appreciated. Also, the authors gratefully acknowledge the assistance of Frank Voss, Washington Water Science Center of the USGS, for compiling GIS data layers and maps for illustrating principal aquifers and well networks of the NAWQA program; and Robert Black, Washington Water Science Center of the USGS, for technical assistance with statistical applications.

\section{References Cited}

American Public Health Association, American Water Works Association, and Water Pollution Control Federation, 1992, Standard methods for the examination of water and wastewater, 18th ed.: Washington, D.C. USA, American Public Health Association, variously paginated.

American Public Health Association, American Water Works Association, and Water Pollution Control Federation, 1998, Standard methods for the examination of water and wastewater, 20th ed.: Washington, D.C. USA, American Public Health Association, variously paginated.

Bickford, T.M., Lindsey, B.D., and Beaver, M.R., 1996, Bacteriological quality of ground water used for household supply, Lower Susquehanna River Basin, Pennsylvania and Maryland: U.S. Geological Survey Water-Resources Investigations Report 96-4212, $31 \mathrm{p}$.

Bisson, J.W., and Cabelli, V.J., 1980, Clostridium perfringens as a water pollution indicator: Journal Water Pollution Control Federation, v. 52, no. 2, p. 241-248.

Bitton, G., 1980, Introduction to Environmental Virology: New York, New York, John Wiley and Sons, Inc., 326 p.

Blackburn, B.G., Craun, G.F., Yoder, J.S., Hill, Vincent, Calderon, R.L., Chen, Nora, Lee, S.H., Levy, D.A., and Beach, M.J., 2004, Surveillance for waterborne-disease outbreaks associated with drinking water-United States, 2001-2002: Centers for Disease Control, MMWR Surveillance Summaries, October 22, 2004, v. 53, no. SS-8, p. 23-45.

Borchardt, M.A., Bertz, P.D., Spencer, S.K., and Battigelli, D.A., 2003, Incidence of enteric viruses in groundwater from household wells in Wisconsin: Applied Environmental Microbiology, v. 69, no. 2, p. 1172-1180, accessed July 2006 at http://www.ncbi.nlm.nih.gov/entrez/query.fcgi?cm $\underline{\mathrm{d}=\text { Retrieve } \& \mathrm{db}=\text { Pubmed \&list uids }=12571044 \& \mathrm{dopt}=\mathrm{Abs}}$ $\underline{\text { tract }}$

Borchardt, M.A., Haas, N.L., and Hunt, R.J., 2004, Vulnerability of drinking-water wells in La Crosse, Wisconsin, to enteric-virus contamination from surfacewater contributions: Applied Environmental Microbiology, v. 70, no.10, p. 5937-5946, accessed July 2006 at http:// www.bionewsonline.com/c/9/mark a borchardt 2004 $\underline{\text { 5937.htm }}$ 
Bowman, Chris, 2005, Many private foothills wells tainted, the state finds widespread contamination in Yuba and El Dorado counties: Sacramento Bee, January 25, 2005, accessed April 2005 at http://www.sacbee.com/content/ news/v-print/story/12118035p-12988707c.html

Britton, L.J., and Greeson, P.E., eds., 1988, Methods for collection and analysis of aquatic biological and microbiological samples: U.S. Geological Survey Techniques of Water-Resources Investigations, book 5, chap. A4, variously paginated.

Bushon, R.N., 2003, Fecal indicator viruses: U.S. Geological Survey Techniques of Water-Resources Investigations, book 9, chap. A7 (3d ed.), section 7.2, accessed July 2005 at http://pubs.water.usgs.gov/twri9A

Cabelli, V.J., 1978, New standards for enteric bacteria: in Water Pollution Microbiology, Ralph Mitchell and Gordon McKay (eds.): New York, John Wiley and Sons, Chapter 9, p. 233-271.

DeBartolomeis, J., and Cabelli, V.J., 1991, Evaluation of an Escherichia coli host strain for enumeration of $\mathrm{F}$ male-specific bacteriophages: Applied Environmental Microbiology, v. 57, no. 5, p. 1301-1305.

Francy, D.S., Helsel, D.R., and Nally, R.A., 2000, Occurrence and distribution of microbiological indicators in groundwater and stream water: Water Environment Research, v. 72, no. 2, p. 152-161.

Francy, D.S., Bushon, R.N., Stopar, Julie, Luzano, E.J., and Fout, G.S., 2004, Environmental factors and chemical and microbiological water-quality constituents related to the presence of enteric viruses in ground water from small public water supplies in southeastern Michigan: U.S. Geological Survey Scientific Investigations Report 2004-5219, 54 p.

Geldreich, E.E., 1966, Sanitary significance of fecal coliforms in the environment: U.S. Department of the Interior, Federal Water Pollution Control Administration, Water Pollution Control Research Publication WP-20-3, 122 p.

Gerba, C.P., 1987, Phage as indicators of fecal pollution, in Goyal, S.M., Gerba, C. P., and Bitton, Gabriel, eds., Phage ecology: New York, John Wiley and Sons, Chap. 8, p. 197-210.

Gilliom, R.J., Hamilton, P.A., and Miller, T.L., 2001, The national water-quality assessment program-Entering a new decade of investigations: U.S. Geological Survey Fact Sheet 071-01, $6 \mathrm{p}$.
Havelaar, A.H., van Olphen, M., and Drost, Y.C., 1993, Fspecific RNA bacteriophages are adequate model organisms for enteric viruses in fresh water: Applied Environmental Microbiology, v. 59, no. 9, p. 2956-2962.

Helsel, D.R., and Hirsch, R.M., 1992, Statistical methods in water resources: New York, Elsevier Science Publishing Company Inc., Studies in Environmental Science 49, 522 p.

International Association on Water Pollution Research and Control Study Group, 1991, Bacteriophages as model viruses in water quality control: Water Research v. 25 , no. 5 , p. 529-545.

Koterba, M.T., Wilde, F.D., and Lapham, W.W., 1995, Ground-water data-collection protocols and procedures for the National Water-Quality Assessment ProgramCollection and documentation of water-quality samples and related data: U.S. Geological Survey Open-File Report 95-399, 113 p.

Lapham, W.W., Wilde, F.D., and Koterba, M.T., 1995, Ground-water data-collection protocols and procedures for the National Water-Quality Assessment ProgramSelection, installation, and documentation of wells, and collection of related data: U.S. Geological Survey Open-File Report 95-398, 69 p.

Lapham, W.W., Hamilton, P.A., and Myers, D.N., 2005, National water-quality assessment program-Cycle II regional assessments of aquifers: U.S. Geological Survey Fact-Sheet 2005-3013, May 2005, accessed July 2005 at http://pubs.usgs.gov/fs/2005/3013/, 4 p.

Maupin, M.A., and Barber, N.L., 2005, Estimated withdrawals from principal aquifers in the United States, 2000: U.S. Geological Survey Circular 1279, 46 p.

Metcalf, T.G., 1978, Indicators for viruses in natural waters, in Mitchell, Ralph and McKay, Fordon, eds., Water Pollution Microbiology: New York, John Wiley and Sons, v. 2, p. 301-324.

McGill, R., Tukey, J.W., and Larsen, W.A., 1978, Variations of boxplots: The American Statistician, v. 32, p. 12-16.

McKee, J.E., and Wolf, H.W., eds., 1963, Water quality criteria ( $2^{\text {nd }}$ ed.): The Resources Agency of California, State Water Quality Control Board Publication No. 3-A, 548 p.

Myers, D.M., and Sylvester, M.A., 1997, National field manual for the collection of water-quality data, biological indicators: U.S. Geological Survey Techniques of WaterResources Investigations, book 9, chapter A7, 49 p. 
Myers, D.N., and Wilde, F.D., eds., November 2003, Biological indicators (3rd ed.): U.S. Geological Survey Techniques of Water-Resources Investigations, book 9, chap. A7, accessed July 2005 at http://pubs.water.usgs. gov/twri9A7/

Palmateer, G.A., Dutka, B.J., Janzen, E.M., Meissner, S.M., and Sakellaris, M.G., 1991, Coliphage and bacteriophage as indicators of recreational water quality: Water Research, v. 25 , no. 3 , p. $355-357$.

Pipes, W.O., ed., 1978, Water quality and health significance of bacterial indicators of pollution, workshop proceedings: Philadelphia, Penn., Drexel University and National Science Foundation, April 17-18, 1978, 228 p.

Scott, J.C., 1990, Computerized stratified random siteselection approaches for design of a ground-water-quality sampling network: U.S. Geological Survey Water-Resources Investigations Report 90-4101, 109 p.

Sobsey, M.D., Amanti, A., and Handzel, T.R., 1995, Detection and occurrence of coliphage indicator viruses in water: Proceedings of the 1995 Water Quality Technology Conference, New Orleans, Louisiana, November 12-16, 1995, American Water Works Association, p. 2087-2097.

U.S. Environmental Protection Agency, 1978, Microbiological methods for monitoring the environment, water and wastes: Office of Research and Development, EPA-600/8-78-017, $338 \mathrm{p}$.

U.S. Environmental Protection Agency, 1996, ICR microbial laboratory manual: Office of Research and Development, EPA/600.R-95/178, 233 p.

U.S. Environmental Protection Agency, 2001a, Total coliform rule-A quick reference guide: Office of Water, November 2001, EPA 816-F-01-035, accessed July 2006 at http:// www.epa.gov/ogwdw/tcr/pdf/qrg_tcr_v10.pdf

U.S. Environmental Protection Agency, 2001b, Method 1601-Male-specific (F+) and somatic coliphage in water by two-step enrichment procedure: Office of Water, EPA 821-R-01-030, 40 p.
U.S. Environmental Protection Agency, 2002a, Method 1103.1: Escherichia coli (E. coli) in water by membrane filtration using membrane-thermotolerant Escherichia coli agar (mTEC): Office of Water, September 2002, EPA 821R-02-020, 17 p.

U.S. Environmental Protection Agency, 2002b, Method 1106.1-Enterococci in water by membrane filtration using membrane-enterococcus-esculin iron agar (mE-EIA): Office of Water, September 2002, EPA 821-R-02-021, 16 p.

U.S. Environmental Protection Agency, 2002c, Method 1604-Total coliforms and Escherichia coli in water by membrane filtration using a simultaneous detection technique (MI Medium): Office of Water, September 2002, EPA 821-R-02-024, 18 p.

U.S. Environmental Protection Agency, 2003, Water on tap, what you need to know: Office of Water, October 2003, EPA 816-K-03-007, accessed July 2006 http://www.epa. gov/safewater/wot/pdfs/book waterontap full.pdf

U.S. Environmental Protection Agency, 2005, Private drinking water wells: Office of Ground Water and Drinking Water, accessed January 2006 http://www.epa.gov/safewater/ privatewells/Index $2 . \mathrm{html}$

U.S. Environmental Protection Agency, 2006, Ground water rule (GWR): Office of Water, accessed October 16, 2006, at http://www.epa.gov/ogwdw/disinfection/gwr/index.html

U.S. Geological Survey, variously dated, National field manual for the collection of water-quality data: U.S. Geological Survey Techniques of Water-Resources Investigations, book 9, chaps. A1-A9, available online at http://pubs.water.usgs. gov/twri9A/

U.S. Geological Survey, 2003, Principal aquifers of the 48 conterminous United States, Hawaii, Puerto Rico, and the U.S. Virgin Islands: U.S. Geological Survey National Atlas, accessed October 2005 at http://www.nationalatlas.gov/mld/ aquifrp.html 
Manuscript approved for publication, November 14, 2006

Prepared by the USGS Publishing Network,

Publishing Service Center, Tacoma, Washington

Bill Gibbs

Bob Crist

Debra Grillo

Bobbie Jo Richey

Sharon Wahlstrom

Chet Zenone

For more information concerning the research in this report, contact the Director, Washington Water Science Center

U.S. Geological Survey, 934 Broadway - Suite 300

Tacoma, Washington 98402

http://wa.water.usgs.gov 


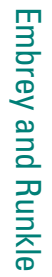

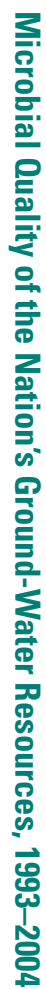

